\begin{tabular}{ccc} 
Coğrafi Bilimler Dergisi & Courafi \\
Bilimler & Dergisi \\
\hline & Turkish Journal of Geographical Sciences & e-ISSN:1308-9765 \\
\hline
\end{tabular}

\title{
Türk Coğrafyacılığında Jenerasyonlar: Disiplinin Tarihine Kohortçu Bir Yaklaşım
}

\section{Generations in Turkish Geography: A Cohort Approach to the History of the Discipline}

\section{Erdem Bekaroğlu*a, Nuri Yavan ${ }^{b}$, Ömer Faik Anlıc}

\begin{tabular}{l} 
Makale Bilgisi \\
\hline DOI: \\
10.33688/ aucbd.502 \\
\hline Makale Geçmişi: \\
Geliş: 25.12 .2018 \\
Kabul: 28.02.2019 \\
\\
\hline Anahtar Kelimeler: \\
Türk Coğrafyacılığ1 \\
Jenerasyon \\
Kohort \\
Doktora Kohortu
\end{tabular}

\section{Article Info}

DOI:

$10.33688 /$ aucbd.502638

Article History:

Received: 25.12 .2018

Accepted: 28.02.2019

Keywords:

Turkish Geography

Generation

Cohort

$\mathrm{PhD}$ Cohorts

\begin{abstract}
$\ddot{\boldsymbol{O}} z$
Bu çalışmanın amacı, Türk coğrafyacılarını birbirinden farklı jenerasyonlara ayırarak disiplinin tarihselliğini aktör grupları perspektifinden irdelemektir. Çalışmada, disiplin içerisinde etkinlik gösteren aktörler kohortçu bir yaklaşımla tanımlanmıştır. Bu tip bir tanımlayıcı-tarihsel çerçevede, aktörlerin doktora tezi hazırlama dönemleri esas alınarak, Türk coğrafyacılı̆̆ındaki jenerasyonların saylsı ve her bir jenerasyonun disiplinin tarihselliğindeki yeri belirlenmeye çalışılmıştır. Buna göre, Türk coğrafyacılı̆̆ı başlangıçtan günümüze 18 jenerasyonla temsil olmaktadır. Bulgular, disiplinin 9. jenerasyona dek bir olgunlaşma dönemini deneyimlediğini, 14. jenerasyondan itibaren niceliksel olarak büyüdüğ̈̈nü, herhangi bir jenerasyonun üye saylsı ile jenerasyonel üretkenlik arasında doğrusal bir ilişkinin olmadı̆̆ını, akademik yeniden-üretim sürecine esas olarak 1990'larda dahil olan çevre üniversitelerdeki jenerasyonların ise zaman içerisinde bir olgunlaşma sürecine girdiğini göstermektedir. Çalışmada, Türk coğrafyacılı̆̆ında 3. jenerasyonun büyük bir ă̆ırlı̆̆a sahip olduğu ve disiplin açısından bir yol bă̆ımlılı̆̆l yarattı̆̆l, bunun 2000'li yılların ilk yarısından itibaren bozulmaya başladığı; bu bakımdan Türk coğrafyacılı̆̆ındaki yenilik ĕ̌ilimlerinin esas olarak son 3 jenerasyonla sinırlı olduğu sonucuna varılmaktadır.
\end{abstract}

\footnotetext{
*Sorumlu Yazar/Corresponding Author: ebekaroglu@ankara.edu.tr

a Ankara Üniversitesi, Coğrafya Bölümü, Ankara, Türkiye, https://orcid.org/0000-0003-0920-9225

b Ankara Üniversitesi, Coğrafya Bölümü, Ankara, Türkiye, https://orcid.org/0000-0002-6752-6598

c Ankara Üniversitesi, Felsefe Bölümü, Ankara, Türkiye, https://orcid.org/0000-0002-5621-5145
} 


\section{Giris}

Bilgi aktarımı, çok çeşitli medyaların kullanılmasıyla gerçekleştirilen ve temel olarak jenerasyon devamlılığına bağlı olan karmaşık bir süreçtir. Bilimsel bilgi bağlamında ele alındığında, bilginin gelişimi üzerine olan ilksel düşünce, bir önceki jenerasyonun ürettiklerinin bir sonraki jenerasyon tarafından geliştirilmesi fikrine dayanır. Bu klasik görüşte, her ne kadar zaman içerisinde kuramsal, metodolojik, teknolojik ve tematik farklılaşmalar görülse de, bilimsel bilgide bir devamlılık olduğu kabul edilir. Bilimsel bilginin gelişiminde var olduğu düşünülen bu devamlılık zamanla hataların ayıklandığı, düzeltildiği ve bilgi seviyesinin sürekli olarak artırıldığı evrimsel bir çerçeveye sahiptir. Uzun bir süre bilimcilerin zihin haritasında önemli bir yere sahip olmuş olan söz konusu klasik düşünce, İkinci Dünya Savaşı sonrasında ortaya çıkan yeni kavrayışlarla zayıflamıştır. Hiç kuşkusuz, buradaki en büyük pay, Thomas Kuhn'un 1962 tarihli “Bilimsel Devrimlerin Yapısı" adlı çalışmasına aittir (Kuhn, 2006). Kuhn'un öne sürdüğü ve bilimsel bilginin jenerasyonlar arası akışkanlığına ilişkin modeli olumsuzlayan paradigma tezi, bilimsel aktivitenin kriz dönemleriyle dolu olduğunu ve söz konusu kriz dönemleri sonucunda ortaya çıkan yeni kuramın, bilimcilerin fenomenleri görme biçimini tümüyle dönüştürdüğünü öne sürmekte; böylelikle de bilimsel bilginin devamlı değil, kesintili bir gelişim çizgisi seyrettiğini ortaya koymaktadır (Anlı, 2016). Ne var ki, bilimsel bilginin jenerasyonel devamlılığa dayalı klasik gelişim modeli, belirli bir periyotta belirli bir disiplini etkisi altına almış olan yeni bir paradigma bağlamında düşünüldüğünde de işler. Zira, yeni paradigmanın ortaya koyduğu yeni kuram, türlü medyalarla jenerasyonlararası bir aktarım sürecine konu olur; bu süreçte hatalar giderilir ve nihayetinde kuram, daha sonra yıkılmak üzere, inceltilir.

Bu bakımdan, 19. yüzyıldan bu yana üniversiter sistem içerisinde kurumsal bir kimlik kazanan akademik ve bilimsel bilgi üretimi (Wallerstein, 2014), verili bir disiplinin üzerine odaklandığ 1 araştırma objesine dair geliştirilen bilgilerin jenerasyonel aktarımına sahne olmaktadır. Coğrafya açısından düşünüldüğünde, temel olarak 19. yüzyılın ikinci yarısında Pan-Avrupa'da akademik olarak inşa edilmeye başlanan disiplinin (Unwin, 1992) bilgi bilimsel yeniden-üretim süreçleri Türkiye'de 20. yüzyılın ilk çeyreğinde, esas olarak yabancı bilimciler ve eğitimlerini Kıta Avrupasında yapan coğrafyacıların öncülük ettiği girişimlerle kurumsallaşmaya bağlamıştır (Erinç, 1973; Tümertekin, 1971).

Bu bağlamda bu çalışmada, ilk defa, akademik olarak 1915 yılında aktif olan Türk coğrafyacılığında etkinlik göstermiş/gösteren aktörler jenerasyonel bir ayrıma tabi tutulmakta ve söz konusu jenerasyon gruplarının davranışı çeşitli parametrelere göre zamansal ve mekansal olarak incelenmektedir. Keşfedici ve makro bir araştırma pratiğini yansıtan bu girişim, Türk coğrafyacılarını kohortçu bir bağlamda jenerasyonlara ayırarak, disiplinin tarihselliğini farklı bir perspektiften aydınlatmayı amaçlamaktadır. Bu doğrultuda çalışma, jenerasyonlar arasındaki bilgibilimsel iletişim süreci ya da aktör grupları arasındaki sosyal ilişkileri değil, jenerasyonların uzun dönemli zamanmekansal eğilimlerini ampirik-analitik bir tarzda irdelemekte ve bu yönüyle Türk coğrafyacıllğını son yıllarda benzer bir metodolojiyle inceleyen çalışmaların (örn. Bekaroğlu ve Sarış, 2017; Bekaroğlu ve Yavan, 2013; 2018; Yavan, 2005; 2019; Yazan ve Bekaroğlu, 2018) bir diğer ayağını oluşturmaktadır.

Çalışma beş bölümden oluşmaktadır. Çalışmanın arka planının işlendiği giriş kısmını, jenerasyonlara ilişkin kuramsal arka planın açımlandığı ikinci bölüm izlemektedir. Jenerasyon kuramının nasıl işlemselleştirildiği ve ayrıca çalışmada kullanılan veri kaynakları yöntem bölümünde 
yer almaktadır. Çalışma, elde edilen bulguların zamansal ve mekânsal örüntüler olarak iki ayrı başlıkta incelendiği dördüncü bölümle devam etmekte; ortaya çıkan bulguların Türk coğrafyacılığının tarihsel gelişimiyle ilişkilendirilerek tartışıldığı beşinci bölümle noktalanmaktadır.

\section{Jenerasyon Kuramı: Kısa Bir Çerçeve}

Jenerasyon (kuşak, nesil), temelde, bir grup bireyin sosyal bütünlük içerisindeki birbiriyle benzer olan lokasyonunu ifade etmektedir. Bu lokasyon, sınıfsal bir yapılanmada olduğu gibi dikey yönlü-hiyerarşik bir konumlanmayı değil, kronolojik bir homojeniteyi yansıtmakta ve biyolojik varoluşun ritmi tarafından belirlenmektedir. Bu bakımdan aynı jenerasyonda olanlar, yani aynı/birbirine yakın yıl/yıllarda doğanlar, sosyal olanın tarihsel boyutundaki ortak bir lokasyona bağlanırlar (Mannheim, 1952). Bu nedenle, aynı jenerasyona ait olanlar, bireysel olanın dışında, belirli birtakım davranış, duygu ve düşünce modu ortaklığını paylaşmaktadır. Böylelikle, jenerasyonların varlığı nedeniyle ortaya bazı sosyal özellikler çıkmaktadır.

Mannheim'a göre (1952), varoluşun süreli bir biyolojik ritme sahip oluşu yüzünden, jenerasyonlar sosyal yaşamın zorunlu bir öğesi olarak ortaya çıkar ve şu temel karakteristikleri yansıtır: Sosyo-kültürel süreçlerdeki önceki katılımcılar devamlı bir şekilde sahneden çekilir (ölümlülük) ve söz konusu süreçlere yeni katılımcılar dahil olur (yeni doğanlar). Eskinin yerini alan yeni bir jenerasyonun herhangi bir üyesi, tarihsel sürecin yalnızca zamansal olarak sınırlı bir kesitinde eyleyebilir (biyolojik yaşam ritmi). Süreç içerisinde birikmiş olan -geniş manadaki- kültürel miras ise, sürekli olarak kuşaktan kuşağa iletilir ve söz konusu değişim kesintisiz bir süreç olarak ilerler.

$\mathrm{Bu}$ bakımdan, birbirinden farklı jenerasyonların belirli bir tarihsel süreci (örneğin bir savaş, rejim değişikliği, ekonomik kriz vb.) birlikte deneyimlemeleri, onların aynı jenerasyona ait olduklarını göstermez. Zira, söz konusu farklı jenerasyonlar ilgili tarihsel süreci yaşamlarının farklı tabakalarında (çocuk, genç, olgun, yaşlı) tecrübe ederler ve bu bakımdan farklı tepkiler verebilirler.

Bununla beraber, aynı jenerasyonel lokasyona sahip olabilmek için aynı/benzer tarihsel-kültürel mekanda da varolmak gerekmektedir. Bu durumun gerçekleşmemesi halinde aynı kuşak içerisinde birbirinden farklı jenerasyon birimleri ortaya çıkmaktadır. Bu nosyon hem mekansal farkl11ık boyutuna hem de aynı mekansal boyuttaki sosyal olaylara verilen farklı tepkilere de işaret etmektedir.

\section{Yöntem}

\section{1. İşlemselleştirme: Kohortçu Yaklaşım}

Jenerasyon teorisinin özünde doğum y1lı ya da kronolojik lokasyondaki ortaklık bulunduğundan, söz konusu çerçevenin bir disiplinin tarihselliğine uygulanarak pasif ve aktif aktör gruplarının kuşaklara ayrılması girişiminde bazı önemli güçlükler ortaya çıkmaktadır. Bu güçlüklerin ilki doğum yılı, ikincisi ise hoca-öğrenci ilişkisi esasına bağlı olarak yapılan ayrımda net olarak görülebilmektedir.

Belirli bir disiplin içerisinde varolan pasif/aktif aktörleri jenerasyonlara ayırma girişiminde izlenebilecek birinci strateji, söz konusu grupları doğum yılı esasına bağlı olarak (nüfus) gruplarına ayırmaktır. Bununla birlikte, birbirine yakın tarihlerde doğanların akademik süreçlere dahil oluşları bir standarta oturmamaktadır. Yani, aynı/birbirine yakın yıllarda doğanlar, örneğin, yaşamlarının farklı noktalarında akademik süreçlere dahil olabilmektedir. Bu ise, sadece doğum yılı esas alındığında, 
birbirinden farklı kronolojik noktalarda akademik yaşamı deneyimleyenlerin aynı jenerasyon içerisinde sınıflandırılmalarına neden olmaktadır. Öte yandan, doğum yılı esas alınarak oluşturulan nüfus kuşaklarında jenerasyon genişliklerinin geniş olması (20-30 yıl), ara kuşakların deneyim farklılıklarını da maskelemektedir.

Belirli bir disiplin içerisinde varolan pasif/aktif aktörleri jenerasyonlara ayırma girişiminde izlenebilecek ikinci strateji, söz konusu aktörleri doktora hocası-doktora öğrencisi olma özelliğine bağl1 olarak gruplara ayırmaktır. Örneğin, Türk coğrafyacılığının iki merkez üniversitesinden biri olan İstanbul Üniversitesi örneğinde, kuruluş yıllarının başat figürlerinden biri olan İbrahim Hakkı Akyol çizgisinin izlediği yollardan biri, hoca-öğrenci ilişkisine dayalı olarak şu şekilde gelişmiştir: İbrahim Hakkı Akyol-Sırrı Erinç-Korkut Ata Sungur-Telat Koç-Canan Zehra Çavuş. Bu örnekte, Türk coğrafyacılığı, Akyol öncesi kurucu jenerasyonlar hariç, beş jenerasyondan oluşmaktadır ve bu, nüfus kuşağı mantığına da hemen hemen oturmaktadır. Lakin, Türk coğrafyacılığının kompozit yapısı dikkate alındığında, bu strateji, disiplinin üyelerini jenerasyonlara ayırma girişiminde standart bir strateji olarak kullanılamaz. Zira, başlıca üç faktör bu düzenliliği bozmaktadır: Bunlardan birincisi, çevre üniversitelerin 1970'ten sonra disipliner yeniden üretim süreçlerine dahil olması; ikincisi, yurtdışında doktorasını tamamlayarak Türk coğrafyacılığında aktör durumuna geçenlerin varlığı; üçüncüsü ve en önemlisiyse, doktora öğrencisi mezun etme safhasının değişimidir: Geçmiştekinin tersine, günümüzde akademik yaşantının daha erken safhalarında doktora öğrencisi mezun etmek mümkündür; bu ise, hocaöğrenci ilişkisine dayalı zamansal dizgeyi bozmaktadır. Bu nedenlerden dolayı, başlangıç aşamasında bir öğrenci yetiştirilmesi ve söz konusu öğrencinin akademik yaşantısının sonraki evrelerinde bir başka öğrenci yetiştirmesiyle devamlılık arz eden örüntü, yine de belirli bir standartı temin edememektedir.

Yukarıda anılan güçlükler nedeniyle bu çalışmada, Türk coğrafyacılığını jenerasyonlara ayırmayı mümkün kılmak için kohortçu bir bağlam işlemselleştirilmiştir. Kohort, belirli bir zamansal periyotta ortak deneyimlere sahip olan bir grup olarak tanımlanmaktadır (Glenn, 2005). Herhangi bir sıfat kullanılmadığında nüfus kuşağına gönderimli olan kohort kavramı, daha çok, ortak özellikler gösteren belirli grupların jenerasyonel tanımında kullanılmaktadır. Örneğin üniversite kohortu, üniversite eğitimine belirli bir yılda başlayıp belirli bir süre sınıfça ortak deneyimler yaşamış bir grubu ifade etmek için kullanılmaktadır. Bu bakımdan, kohortçu bir tanımlamanın hangi zaman aralıklarını kapsadığının bir standartı yoktur. Zira, bir yıllık bir süre boyunca askerlik görevini icra eden devrelerin kohort aralığı bir yıl olarak, tıp öğrenimi gören öğrencilerin kohort aralığı altışar yıllık örgün eğitim süresi göz önüne alınarak belirlenebilir.

Türk coğrafyacıllı̆gndaki aktörleri kohortçu bir bağlamda birbirinden farklı jenerasyonlara ayırma girişiminde, doğum yılı ya da hoca-öğrenci ilişki zinciri ne olursa olsun, aktörlerin doktora eğitimi süreci ayırt edici bir standart olarak kabul edilmiştir. Gerçekten, doktora kohortları, bu tip bir çalışmada bir standart olarak göz önüne alınabilecek en uygun ölçüdür. Zira, doğum y1lı ya da hocaöğrenci ilişkisi içerisindeki konumu ne olursa olsun, benzer dönemde benzer bir eğitimi alanlar; yani, aynı dönemdeki hocalardan ders alıp, benzer kitapları okuyanlar, benzer sınavlardan geçerek, birbirine yakın akademik süreçleri deneyleyerek mezun olanlar, Kuhncu anlayışla, benzer bir paradigmatik forma da sahip olabilmektedir. Benzer paradigmatik forma sahip olabilen bu gruplar, jenerasyon teorisinin en önemli parametrelerinden biri olan belirli birtakım davranış, duygu ve düşünce modu ortaklığını da paylaşmaktadır. Üstelik bu, bilimsel olduğu kadar kültürel bir ortalığa da işaret edebilmektedir. İşte bu 
yüzden, çalışmada, disipliner yeniden üretim sürecinin en önemli öğesi olan doktora eğitimine dahil olan bireyler birlikte bir kohort olarak değerlendirilmektedir ${ }^{1}$.

Genel olarak 4-6 yıl sürebilen doktora yapma süreci, kohort ayrımında standart olarak 5 yıl olarak alınmış ve her bir 5'er yıllık süreçte doktora eğitimini tamamlamış olanlar aynı kohort altında sınıflandırılmıştır. Söz konusu sınıflandırmada kohortlar hem eskiden yeniye doğru artan sayılarla (örneğin, 1. jenerasyon, 2. jenerasyon vb.) hem de söz konusu 5 y1llık zamansal periyodun orta noktasına gelen yılla (örneğin, 1955-1959 yılları arasında doktorasını tamamlayanlar 1957 kuşağı olarak) işaretlenmiştir. Türk coğrafyacılığında sistematik olarak 1943 yılında başlayan doktoralı bilimci yetiştirme sürecinden önce disiplin içerisinde aktif olan aktörler ise "kurucu" jenerasyonlar olarak etiketlenmiş ve etkinlik gösterdikleri periyotlar dikkate alınarak 10'ar yıllık aralıklarla kendi içerisinde gruplanmıştır.

\subsection{Veri Kaynağı: Doktora Tezleri}

Türk coğrafyacılığının kohortçu bir bağlamda jenerasyonlara ayrılması işleminde disipliner yeniden-üretim süreçleri odakta olduğundan, coğrafya alanında doktora yapmış ve aynı zamanda akademisyen olmuş/olan aktörler dikkate alınmıştır.

Bu bakımdan, 1943-2014 yılları arasını kapsayan doktora tezlerine ilişkin veri serisi üç farklı kaynaktan elde edilmiştir. Bunlardan ilki, YÖK Ulusal Tez Merkezi veri tabanıdır (YÖK, 2018). Bu veri tabanı, bazı eksikliklerine rağmen, 1978 sonrası coğrafyacılar tarafından yazılmış doktora tezlerini kapsamaktadır. İkinci veri kaynağı, İstanbul Üniversitesi Merkez Kütüphanesi (ÏUMK, 2015) ile Ankara Üniversitesi, Dil ve Tarih-Coğrafya Fakültesi Kütüphanesi'nin (AÜDTCF, 2015) tez katalogları olmuştur. Bu iki merkez üniversitede 1943-1978 y1lları arasında verilen tüm doktora tezleri, ilgili kütüphanelere yapılan ziyaretler ve arşiv araştırmalarıyla elde edilmiştir. Çalışmanın son veri kaynağı ise, Türkiye'de coğrafya bölümlerinde çalışan ve doktorasını yurtdışından elde eden 26 coğrafyacıya ait kayıttan oluşmaktadır (Yurtdış1, 2017). Bu veri hem Almanya, Fransa, İngiltere ve ABD’nin ulusal kütüphanelerinden hem de bunun yetmediği durumlarda doktoraların verildiği ilgili üniversitelerin kütüphaneleri ile ProQuest tez veri tabanından [ProQuest Dissertations \& Theses (PQDT) database] elde edilmiştir.

\subsection{Analiz Parametreleri}

Türk coğrafyacıllı̆ında etkinlik göstermiş/gösteren jenerasyonların başlangıçtan günümüze dek sergiledikleri eğilimler çalışmada yedi kategori altında incelenmektedir:

1- Jenerasyon üye sayıs1

2- Baskin jenerasyonlar

3- Baskın jenerasyonun -yetiştirilen jenerasyona olan- uzaklığ

4- En uzak jenerasyon fark1

5- En yakın jenerasyon fark1

6- Jenerasyon üye sayısı ile üretkenliği arasındaki ilişki

7- Baskın jenerasyonların üretkenlik performansının zamansal değişimi 
Jenerasyon üye sayısı, çalışmada uygulanan işlemselleştirme stratejisi takip edilerek kohortlara ayrılan her bir grubun üye sayısını ifade etmektedir. Baskın jenerasyon, aslında bir jenerasyonun üretiminde en büyük paya sahip olan kohorta işaret etmektedir. Bu bakımdan, üretilen her bir jenerasyon üyesinin bir doktora danışmanı bulunmaktadır. Bu doktora danışmanları ise daha eski bir başka jenerasyonun üyesi durumdadır. Bu bakımdan baskın jenerasyon, her bir jenerasyonu üreten kuşağın (doktora danışmanlarının) söz konusu üretim sürecindeki ağırlığını ölçmektedir. Bu ölçüm, bir jenerasyonu yetiştiren üretici kuşakların mod özelliğiyle ortaya çıkmaktadır. Örneğin, 13. jenerasyonu yetiştiren kuşak içerisinde 6, 8, 9 ve 10. jenerasyonun üyesi olan aktörler bulunmaktadır. Ancak, toplam 12 üyesi olan 13. jenerasyonun üretiminde 7 danışmanlıkla en büyük pay 8. kuşağa aittir. Bu nedenle, 13. kuşak bağlamında düşünülürse, baskın jenerasyon 8. jenerasyondur. Baskın jenerasyonun uzaklığı, belirli bir jenerasyonun üretiminde baskın rol oynayan kuşağın, yetiştirilen nesile olan jenerasyonel uzaklığını ifade etmektedir. Yukarıdaki örnekten hareketle, 13. jenerasyon açısından baskın kuşak olan 8. jenerasyon bağlamında baskın jenerasyonun uzaklı̆̆ı beştir. En uzak jenerasyon farkı, bir jenerasyonun üretilmesinde pay sahibi olan (üretici) jenerasyonlar arasında, üretilen jenerasyona en uzakta yer alan kuşağı tanımlamaktadır. Bu bakımdan, 13. jenerasyonun üretiminde pay sahibi olan kuşaklardan yetiştirilen jenerasyona en uzak pozisyonda olan 6. jenerasyondur. Dolayısıyla, 13. kuşak bağlamında en uzak jenerasyon farkı 7 'dir. En yakın jenerasyon farkı ise, bir kuşağın üretilmesinde pay sahibi olan (üretici) jenerasyonlar arasında, üretilen nesile en yakında yer alan kuşağı tanımlamaktadır. Bu bakımdan, 13. jenerasyonun üretiminde pay sahibi olan kuşaklardan yetiştirilen jenerasyona en yakın pozisyonda olan 10. jenerasyondur. Dolayısıyla, 13. kuşak bağlamında en yakın jenerasyon farkı 3 'tür. Jenerasyon üretkenliği (Jenerasyon üye sayısı ile üretkenliği arasındaki ilişki), verili bir jenerasyonun üye sayısı ile üretilmesinde pay sahibi olduğu jenerasyonlar içerisindeki üye sayısı arasındaki ilişkiyi ölçmektedir. Baskın jenerasyonların üretkenlik performansının zamansal değişimi ise, 6 ve üstü sayıda jenerasyon yetiştirilmesinde payı olmuş olan kuşakların, yetiştirici kuşak olma bakımından gösterdiği zamansal dizgeyi ifade etmektedir. Bu bakımdan, örneğin, 10. jenerasyonun yetiştirici kuşak olma özelliği 16. jenerasyonda maksimum yapmıştır. Yani, 10. jenerasyon açısından üretkenlik perfomansı 6 kuşak öncesi ve sonrasında sönümlenmekte; bu bakımdan bir çan eğrisi oluşmaktadır.

\section{Bulgular: Türk Coğrafyacılığında Jenerasyonlar}

\subsection{Zamansal Eğilimler}

Türk coğrafya pratiği, akademik bir disiplin olarak, başlangıcından günümüze toplam olarak 18 jenerasyonla karakterize olmaktadır (Çizelge 1). Bu serinin ilk üç jenerasyonu kurucu bilimcilerden ${ }^{2}$ $(n=15)$, geri kalanı ise üretilen jenerasyonlardan ${ }^{3}(n=409)$ oluşmaktadır (tüm liste için bkz. EK 1).

Türk coğrafyacılığındaki jenerasyonlar 3-13. kuşaklar arasında ortalama olarak 7 kişiyle temsil olurken, bu oran 14-18. kuşaklar arasında 66'ya çıkmaktadır. Bu bakımdan, Türk coğrafyacılığındaki niceliksel büyüme esas olarak 14. jenerasyonla başlamıştır (Şekil 1a).

Tüm jenerasyonlar bakımından değerlendirildiğinde, Türk coğrafyacılığındaki baskın jenerasyonlar şunlardır (Şekil 1b): 3. jenerasyon, 4. jenerasyon, 8. jenerasyon, 9. jenerasyon, 11. jenerasyon, 14. jenerasyon. 
Çizelge 1. Türk coğrafyacıllı̆ında jenerasyonlar

\begin{tabular}{|c|c|c|c|c|c|c|c|c|c|c|c|c|c|c|c|c|c|}
\hline \multicolumn{3}{|c|}{ Kurucular } & \multicolumn{15}{|c|}{ Jenerasyonlar } \\
\hline 1915 & 1925 & 1935 & 1942 & 1947 & 1952 & 1957 & 1962 & 1967 & 1972 & 1977 & 1982 & 1987 & 1992 & 1997 & 2002 & 2007 & 2012 \\
\hline 1 & 2 & 3 & 4 & 5 & 6 & 7 & 8 & 9 & 10 & 11 & 12 & 13 & 14 & 15 & 16 & 17 & 18 \\
\hline 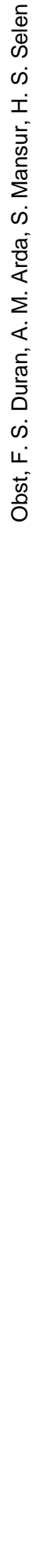 & 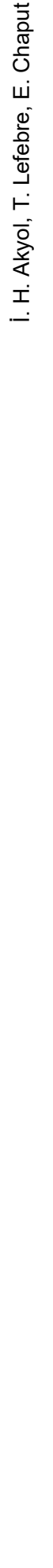 & 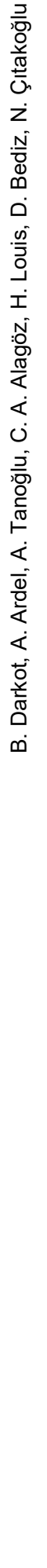 & 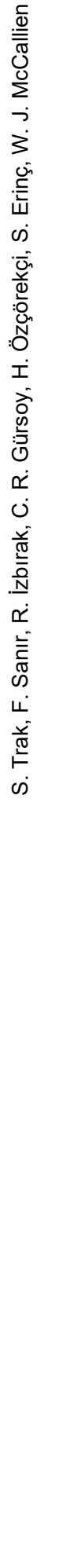 & 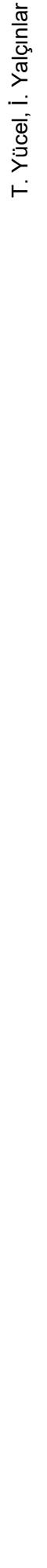 & 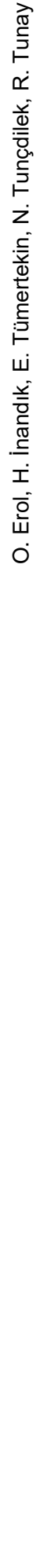 & 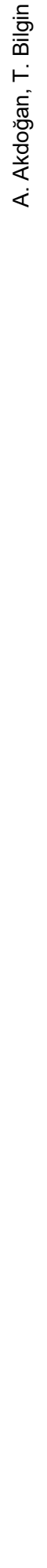 & 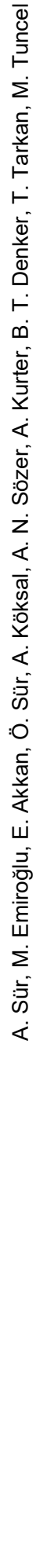 & 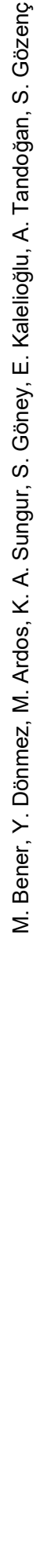 & 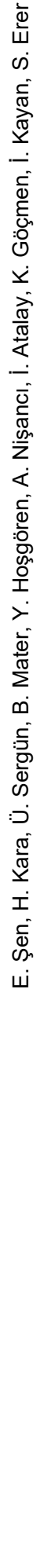 & 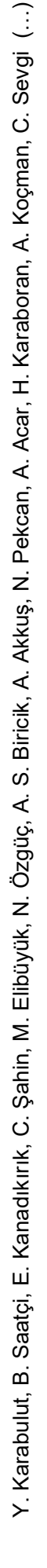 & 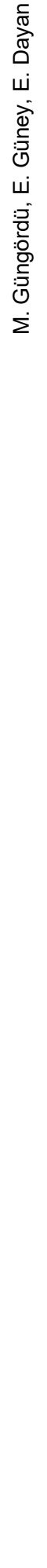 & 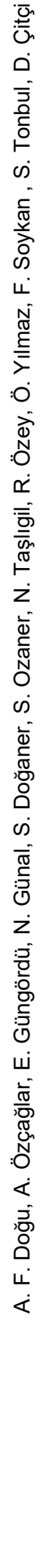 & 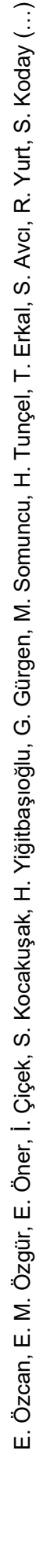 & 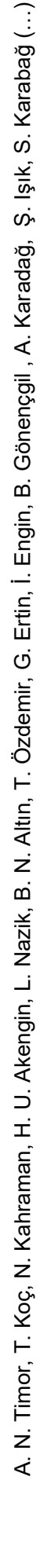 & 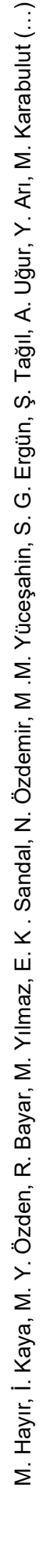 & 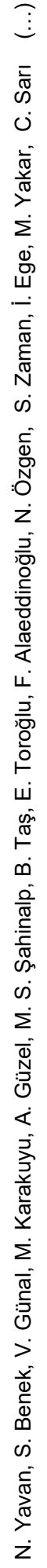 & 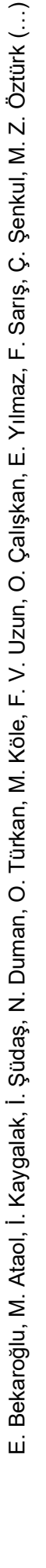 \\
\hline
\end{tabular}



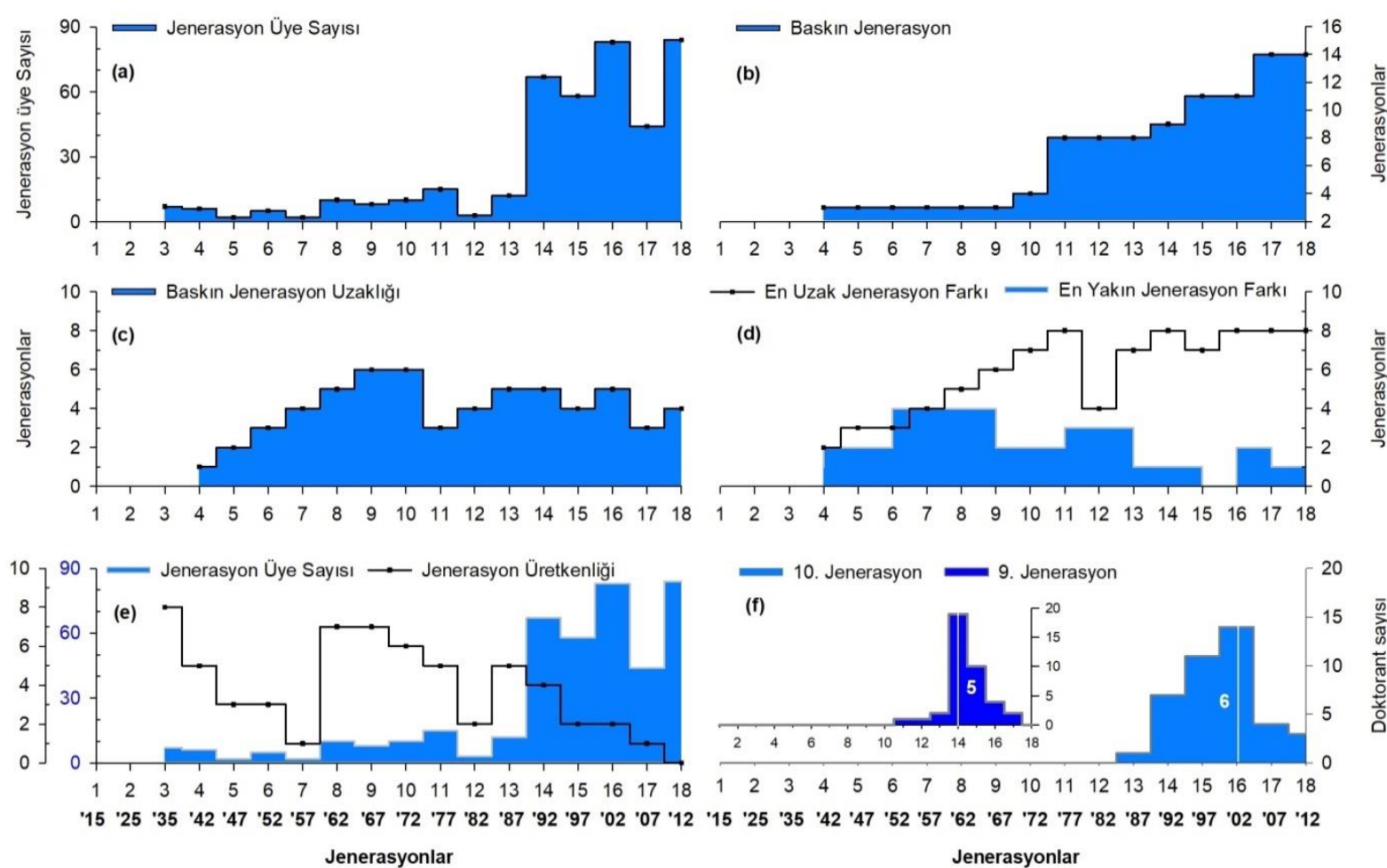

Şekil 1. Türk coğrafyacılığındaki jenerasyonların sergilediği zamansal eğilimler. (a) Jenerasyonların üye sayısı, (b) Jenerasyonların üretiminde baskın rol oynayan yetiştirici kuşaklar, (c) Her bir jenerasyonun üretiminde baskın rol oynamış olan jenerasyonun yetiştirilen kuşağa jenerasyonel uzaklığı, (d) Yetiştirilen kuşağa en uzak ve en yakın olan kohortlar, (e) Jenerasyon üye sayısı ile jenerasyon üretkenliği arasındaki ilişki, (f) Türk coğrafyacılığında $\geq 6$ kuşağın üretilmesinde katkısı bulunan jenerasyonların zamansal üretkenlik performansı.

Bunlar içerisinde, disipliner yeniden-üretim sürecine bir jenerasyondan fazla hakimiyet kurmuş olanlar bir plato eğrisi oluşturmaktadır. Bu bakımdan ele alındığında, disiplin içerisinde en etkili aktör grupları 3., 8., 11. ve 14. jenerasyonun üyelerinden oluşmaktadır. Bunlar içerisinde, 3. jenerasyonun 6 kuşak boyunca baskın bir rol oynamış olduğu son derece dikkat çekicidir.

Baskın jenerasyonun, üretimi sürecinde aktif olduğu kuşağa uzaklığına bakıldığında, Türk coğrafyacılığının ilk yerli jenerasyonlarının üretildiği 4. kuşaktan 10. kuşağa kadar sürekli olarak bir uzaklaşma eğilimi gözlenmektedir (Şekil 1c). 11. jenerasyonla yakınsak eğilimler göstermeye başlayan baskın jenerasyonların üretilen kuşaklara olan uzaklı̆g 12 . jenerasyondan itibaren 4 kuşaklık bir ortalamayla seyretmektedir.

Yetiştirilen kuşağa en yakın olan ile en uzak olan üretici jenerasyonlar arasındaki farka ilişkin zamansal örüntü değerlendirildiğinde (Şekil 1d), söz konusu farkların 9. jenerasyona kadar minimum olduğu, örüntünün esas olarak 12. jenerasyondan sonra değişerek artmaya başladığı ortaya çıkmaktadır.

Türk coğrafyacılığında her bir jenerasyonun üye sayısı ile söz konusu jenerasyonun yetiştirdiği aktör sayısı arasında doğrusal bir ilişki bulunmamaktadır (Şekil 1e). Jenerasyon üretkenliği bu nedenle aktör bağımlı bir tabiata sahiptir. Belirli bir jenerasyondaki üyeler, diğer jenerasyonlara göre daha fazla doktorant yetiştirebilmekte, ancak benzer bir eğilim jenerasyonun diğer üyelerinde sistematik bir şekilde gözlenmemektedir. 

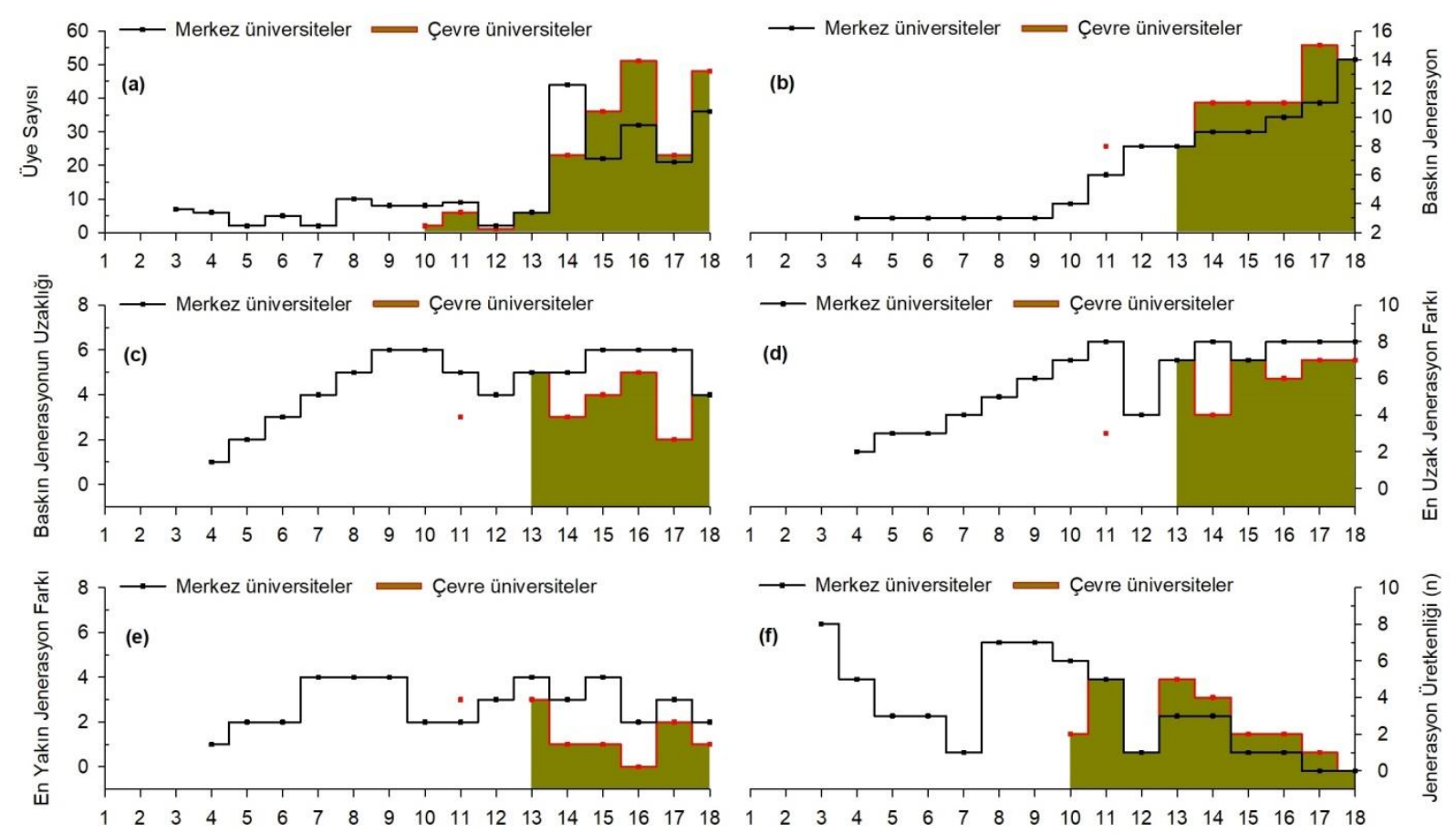

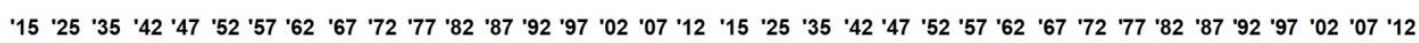

Şekil 2. Merkez ve çevre üniversitelerdeki jenerasyonların sergilediği zamansal eğilimler. (a) Merkez ve çevre üniversiteler bağlamında jenerasyonların üye sayısı, (b) Merkez ve çevre üniversitelerdeki jenerasyonların üretiminde baskın rol oynayan yetiştirici kuşaklar, (c) Merkez ve çevre üniversitelerdeki her bir jenerasyonun üretiminde baskın rol oynamış olan jenerasyonun yetiştirilen kuşağa jenerasyonel uzaklığı, (d) Merkez ve çevre üniversitelerdeki üretici jenerasyonların yetiştirilen kuşağa en uzak olan jenerasyonların zamansal değișimi, (e) Merkez ve çevre üniversitelerdeki üretici jenerasyonların yetiştirilen kuşağa en yakın olan jenerasyonların zamansal değişimi, (f) Merkez ve çevre üniversitelerdeki jenerasyon üretiminde katkısı bulunan jenerasyonların zamansal üretkenlik performansı.

Türk coğrafyacılığında bir jenerasyonun üretkenliği 8 kuşakla sınırlıdır. Disiplinde $\geq 6$ jenerasyonun üretiminde katkısı olan kuşaklar dikkate alındığında, söz konusu kuşakların doktorant yetiştirme performanslarının yetiştirilen 5. ya da 6. jenerasyonla maksimuma çıktığı gözlenebilmektedir (Şekil 1f). Yani, belirli bir jenerasyonun üyelerinin üretkenlikleri 25-30 yıl sonra maksimum yapmakta, sonrasında ise bir azalma eğilimine girmektedir. Bu bakımdan, 9. ve 10. jenerasyonların sergilediği örüntü oldukça dikkat çekicidir.

\subsection{Mekânsal Eğilimler}

Türk coğrafyacılığındaki disipliner yeniden üretim süreçleri tek bir mekanda gerçekleşmediğinden ve üstelik söz konusu üretim 1970'lerin sonundan itibaren çevre üniversitelere de yayıldığından, disiplin içerisinde birbirinden farklı jenerasyon birimleri ortaya çıkmıştır. Türk coğrafyacılığındaki jenerasyonların gelişsiminde bu farklı jenerasyon birimlerinin etkisini ölçmek amacıyla disiplindeki jenerasyonların mekansal eğilimleri bu kısımda irdelenecektir.

$\mathrm{Bu}$ irdeleme, jenerasyonların zamansal davranışlarını merkez üniversiteler (Ankara ve İstanbul üniversiteleri) ile çevre üniversiteler (merkez üniversiteler dışındaki diğer doktorant yetiştiren üniversiteler) bağlamında ele almaktadır ${ }^{4}$. 
Merkez üniversiteler, disipliner yeniden-üretim sürecine 10. jenerasyona kadar tümüyle hakim olmuştur (Şekil 2a). Çevre üniversiteler ise sürece 11. jenerasyonla ama esas olarak 13. jenerasyonla dahil olmuştur. Söz konusu periyotta coğrafyacılar 13 farklı bölümden (ve ayrıca yurtdışındaki muhtelif üniversitelerden) derece almışlardır. Çevre üniversitelerden alınan doktora derecelerinin \% 42'si Atatürk Üniversitesi'ne, \% 17'si Firat Üniversitesi'ne, \% 11.5'i Marmara Üniversitesi'ne, \% 8.5'i Ege Üniversitesi'ne, \% 5.7'si ise 9 Eylül Üniversitesi'ne aittir (Diğer: \%15.5).

Jenerasyonların üye sayıları bakımından ele alındığında, merkez üniversitelerin 10-14. jenerasyonlar arasında varolan niceliksel üstünlüğünün 15. jenerasyondan itibaren çevre üniversiteler lehine bozulduğu görülmektedir (Şekil 2a). Bu bakımdan, son 4 jenerasyonun üretiminde çevre üniversiteler daha etkindir.

Çevre üniversitelerdeki disipliner yeniden-üretim sürecinde 8., 11., 14. ve 15. jenerasyonların baskınlığı öne çıkmaktadır (Şekil 2b). Bunlar içerisinde 11. jenerasyonun sahip olduğu ağırlık oldukça dikkat çekicidir. Bir diğer özellik ise, çevre üniversitelerdeki baskın kuşakların merkez üniversitelerdeki muadillerinden genel olarak daha genç aktör gruplarıyla karakterize olmasıdır.

Bununla birlikte, çevre üniversitelerdeki baskın jenerasyonla merkez üniversitelerdeki baskın jenerasyon son kuşakta eşitlenmiştir.

Baskın jenerasyonun üretilen kuşağa olan uzaklığı göz önüne alındığında, merkez üniversitelerde üretilen jenerasyonların yetiştirici kuşakları, çevre üniversitelerdekine oranla hemen hemen daima daha olgun gruplardan oluşmaktadır (Şekil 2c). Bu bakımdan, çevre üniversitelerdeki jenerasyonların yetiştirilmesinde daha genç olan baskın kuşakların hakimiyeti söz konusudur.

Merkez üniversitelerde, çevre üniversitelere göre daha eski kuşakların doktorant yetiştirme süreçlerinde etkin oldukları görülmektedir (Şekil 2d). Bununla birlikte, bu fark, özellikle son iki kuşakta kapanmış ve duraylı bir hale gelmiştir.

Merkez üniversitelerdeki en yakın yetiştirici kuşağın yetiştirilen jenerasyondan farkı, çevre üniversitelerde gözlenen örüntüden farklıdır. Çevre üniversitelerde zaman içerisinde giderek gençleşme eğilimi gözlenmektedir (Şekil 2e). Çevre üniversitelerdeki jenerasyonların yetişmesinde göreceli olarak daha genç kuşakların katkısı bulunmaktadır.

Merkez-çevre ikiliği çerçevesinde ele alındığında, çevre üniversitelerin üretkenliğinin 13. kuşaktan itibaren daha fazla olduğu görülmektedir (Şekil 2f). Halen aktif olan jenerasyonların çevre üniversitelerdeki üyelerinin daha fazla jenerasyonun üretilmesinde payları söz konusudur.

\section{Tartışma ve Sonuç}

Türk coğrafya pratiğini jenerasyonel bir ayrıma tabi tutarak söz konusu jenerasyon gruplarının davranışını kohortçu bir bağlamda ve çeşitli parametrelere göre inceleyen bu çalışmadan elde edilen bulgular zamansal olarak toplu olarak değerlendirildiğinde, kurumsal genişlemesi ve akademik nüfus olarak büyümesi 14. jenerasyonla başlayan Türk coğrafyacılığında en baskın kuşakların sırasıyla 3, 8, 11 ve 14. jenerasyonun üyelerinden oluştuğu, baskın jenerasyonun yetiştirilen kuşağa olan uzaklığının 9. jenerasyona dek sistematik olarak arttığı ve 12. jenerasyon itibariyle ortalama olarak 4 kuşakta dengelendiği; 9. jenerasyona kadar çok az olan yetiştirici/yetiştirilen jenerasyon farkının 12 . jenerasyondan sonra maksimum seviyeye eriştiği, jenerasyon üye sayısı ile jenerasyon üretkenliği 
arasında anlamlı bir ilişkinin olmadığı ve maksimum 8 kuşakla sınırlı olan jenerasyon üretme yeteneğinin ise, 5 . ya da 6 . kuşakla maksimum yaptığ 1 görülmektedir.

Çalışmanın bulguları mekansal olarak değerlendirildiğindeyse, disipliner yeniden-üretim sürecine 11. jenerasyonla dahil olan çevre üniversitelerin 15. jenerasyondan itibaren bu sürece hakim olduğu, çevre üniversiteler özelinde özellikle 11. ve 15. jenerasyonun baskın kuşak olarak öne çıktığı, çevre üniversitelerdeki yetiştirici kuşakların merkez üniversitelerdeki örüntüye göre hem daha az olgun hem de daha genç aktörlerden oluştuğu ve jenerasyon üretkenliği bakımından çevre üniversitelerdeki kuşakların 13. jenerasyondan itibaren üstünlük sağladığı ortaya çıkmaktadır.

$\mathrm{Bu}$ değerlendirmeler göz önüne alındığında, Türk coğrafyacılığının jenerasyonel kompozisyonunun ortaya koyduğu bir dizi temel sonucun altı çizilebilir. Bunlardan birincisi, Türk coğrafyacılığının 9. jenerasyona, yani 1970'lere dek jenerasyonel anlamda bir olgunlaşma dönemini deneyimlemesidir. Gerçekten, gerek baskın jenerasyonun yetiştirilen kuşağa olan uzaklığ (Şekil 1c), gerekse de yetiştirici kuşağın yetiştirilen kuşağa olan uzaklığ (Şekil 1d), disiplinin 1970'lere dek bir olgunlaşma dönemini yaşadığına işaret etmektedir. Türk coğrafya pratiği, 10. jenerasyondan beri göreceli olarak daha duraylı özellikler göstermekte ve bu kompozisyon hem baskın jenerasyonun yetiştirilen kuşağa olan uzaklığına hem de yetiştirici kuşakların yetiştirilen jenerasyona olan mesafesine yansımaktadır. Bu bakımdan, disiplindeki baskın jenerasyonun yetiştirilen kuşağa olan uzaklığı ortalama olarak 4 jenerasyondur. İkincisi, Türk coğrafyacılığındaki jenerasyonların üye sayılarının 14 . jenerasyonla birlikte bir önceki dönemle karşılaştırılamayacak denli artmasıdır (Şekil 1a). Kendi içerisinde üniversiter sistemin mekansal olarak genişlemesi sürecini de barındıran bu durum (Yavan, 2012) disiplindeki aktörlerin sayısına da yansımış; 14. jenerasyona kadar ortalama olarak 7 kişi olan jenerasyon üye sayıs1, 14. jenerasyon itibariyle ortalama olarak 66'ya yükselmiştir. Üçüncüsü, bir jenerasyonun üye sayısı ile söz konusu jenerasyonun üretkenliği (doktora öğrencisi yetiştirme sayısı) arasında doğrusal bir ilişkinin olmayışıdır (Şekil 1e). Bu, üretkenlik bağlamında ele alındığında, jenerasyonun sahip olduğu üye sayısından ziyade, jenerasyon içerisindeki üyelerin duygusal enerjisiyle (Collins, 1998) açıklanabilecek bir duruma da işaret etmektedir. Bağlı olunan jenerasyonun üye sayısından bağımsız olarak, duygusal enerjisi fazla olan aktörlerin üretkenlikleri, diğer potansiyel faktörler sabitlendiğinde, diğerlerine oranla daha fazla olmaktadır. Ancak, buradaki bağlamıyla jenerasyonların akademik üretkenliklerinin de bir sınırı vardır. Bu bakımdan üst sınır, tümüyle genç bir jenerasyon tarafından kurumsallaştırılan disiplinlerde 8 jenerasyondur. Söz konusu üst sınır, disiplinlerin olgunlaşma sürecini deneyimlemeleriyle düşmektedir. Türk coğrafyacıllı̆ında jenerasyonların üretkenliği ideal koşullarda 5. ya da 6. kuşakta maksimum yapmaktadır. Dördüncüsü, akademik yeniden-üretim sürecine esas olarak 1990'larda dahil olan çevre üniversitelerdeki jenerasyonların zaman içerisinde bir olgunlaşma sürecini deneyimlemesidir. $\mathrm{Bu}$ süreçte çevre üniversitelerdeki baskın jenerasyonun merkez üniversitelerdeki baskın jenerasyonla eşitlendiği (Şekil 2b), yetiştirilen jenerasyona olan uzaklığın giderek arttığı (Şekil 2d) ve ayrıca, jenerasyonel üretkenliğin merkez üniversitelerdeki kuşakların üretkenliğini geçtiği gözlenmektedir (Şekil 2f).

$\mathrm{Bu}$ genel değerlendirmelerden sonra, yakın plana alınması gereken iki husustan birini 3. jenerasyon olarak etiketlenen ve kendisinden sonraki 6 jenerasyonun üretiminde en baskın rolü oynamış olan aktör grubunun Türk coğrafya pratiğinde oynadığı baskın rol, diğerini ise disiplinin 2000'li yılların ilk yarısından beri deneyimlemekte olduğu yenileşme sürecinin jenerasyonel bağlamı oluşturmaktadır. 
Türk coğrafyacıllğında 3. jenerasyon olarak etiketlenen grubun üyeleri (B. Darkot, A. Ardel, A. Tanoğlu, C. A. Alagöz, H. Louis, D. Bediz, N. Çıtakoğlu) -ikinci jenerasyonun üyesi olan ama aynı kuşağın diğer üyelerinin aksine akademik aktivitesini devam ettiren İ. H. Akyol'la birlikte ele alındığında-, eğitimlerini 1920-30'lu yıllarda genç cumhuriyetin sağladığı olanaklarla yurtdışında (temel olarak Fransa, Almanya, İsviçre ve Avusturya'da) yapmış; 1933 üniversite reformu (Günergun, 2010) sonrasında ülkedeki iki (merkez) üniversitenin coğrafya bölümlerinde görev almış kişiliklerdir. Dönemin hakim coğrafya okullarında okumuş ve bazıları Baulig, de Martonne, Demangeon gibi ünlü coğrafyacıların öğrencisi olmuş olan bu jenerasyon (Erinç, 1973; Tümertekin, 1971), Türkiye'deki modern coğrafyacılığın kurucularıdır. Öyle ki, söz konusu kuşak yalnızca kurumsal anlamda değil ama esas olarak akademik anlamda Türkiye'deki modern coğrafyacılığın gaiası durumundadır ve kendisinden önce coğrafya olarak nitelendirilebilecek olan kaynakları yaptıkları yayınlarda neredeyse hiç kullanmamıştır ${ }^{5}$. Bu, disiplinin Türkiye'deki kuruluş felsefesinin, coğrafyanın Pan-Avrupa' daki inşa süreçlerinin jenerasyonel aktarımının (Dickinson, 1968) mirası üzerine temellendiğini ve makro ölçekte değerlendirildiğinde, Alman ve Fransız coğrafya okullarının önderlik ettiği paradigmatik forma uygun bir yapılanma sergileyen Türk coğrafyacılığının (Bekaroğlu ve Yavan, 2013; Erinç, 1973), Osmanlı İmparatorluğu'nun muhtelif dönemlerinde coğrafi olarak nitelendirilebilecek (bkz. Akyol, 1943; Gümüşçü ve Özür, 2016) ya da Kuhncu anlamda bilim-öncesi bir aktiviteyi yansıtan pratikler yahut aktörlerle dikkate değer jenerasyonel bir ilinti taşımadığını göstermektedir. Tam aksine bir cumhuriyet projesi olan ve modernist bir çizgide gelişen Türk coğrafyacılığındaki (bkz. Darkot, 1951) bu kurucu jenerasyon, Kıta Avrupasında olgunlaşan modern coğrafyanın fikri transferini yapmış ve disiplinin kuruluş felsefesini bu paradigmaya göre inşa etmiş aktörlerden oluşmaktadır. Nitekim, Türk coğrafyacılığındaki 3. jenerasyonun aktif olduğu dönem boyunca disiplindeki hakim gelenek, sosyal olanı koşulladığı düşünülen yerbilimi geleneği (Bekaroğlu ve Sarış, 2017; Bekaroğlu ve Yavan, 2018), etkilenilen coğrafya okulu ise Kıta Avrupası kökenliydi (Bekaroğlu ve Yavan, 2013). Böyle bir arka plana bağlı olarak disiplin, 1940'lı yılların ilk yarısına gelindiğinde temel kurumsallaşma aşamalarını tamamlamış (Bekaroğlu, 2014) ve bu tarihten itibaren yerel bir entelektüel merkez olma hüviyetine kavuşmuştur (Bekaroğlu, 2016). Yerel bir entelektüel merkez olma özelliği, diğerlerinin yanı sıra, doktorant yetiştirme sürecini de kapsamaktadır. $\mathrm{Bu}$ açıdan değerlendirildiğinde Türk coğrafyacılığındaki 3. jenerasyon, 1940'lardan itibaren kendisinden sonraki 6 jenerasyonun yetiştirilmesinde baskın bir rol oynamıştır. $\mathrm{Bu}$, yalnızca, göreceli olarak genç bir kuşak tarafından yeni inşa edilen bir disiplinde görülebilecek olan bir özelliktir. Nitekim, 3. jenerasyon, yetiştirilmesinde baskın bir rol oynadığ 1 kendisinden sonraki 6 kuşaktan adeta merdiven basamaklarını andıran bir şekilde zamanla uzaklaşmış (Şekil 1c); yani olgunlaşmış ve mantıksal olarak beklenebileceği üzere, disiplinin ontolojik ve epistemolojik olarak ne olduğu üzerine herhangi bir ihtilafın olmadığı bu dönemde, bilim yapma pratiğini -muhtemelen- belirlemiştir. Bu kompozisyon, Türk coğrafyacılığındaki güçlü holistik (bölgesel, sentezci) yapının köklenmesindeki -tekrar üretilmesindeki değil-temel dinamiklerden biri ama en önemlilerinden biri- olabilir. Zira, disiplinin 20. yüzyılın ikinci yarısında Anglo-Amerikan dünyada yaşadığı baş döndürücü değişimleri (Johnston, 2017) 1skalamasının (Tekeli, 2010) ya da reddetmesinin (Bekaroğlu, 2016) tarihsel derinliği, Kıta Avrupasındaki hakim coğrafya okullarında okuyup dönemin coğrafya anlayışını ülkede kurumsal olarak inşa eden; disiplinin İkinci Dünya Savaşı'ndan sonra değişmeye başlayan doğasından haberdar olmayan ya da haberdar olsa bile buna savunmacı bir şekilde yaklaşan ve bu fikri arka plan çerçevesinde doktorant yetiştirmiş olan 3 . 
jenerasyonun aktif olduğu dönemin bağlamında bulunabilir. Çünkü, daha önce ifade edildiği gibi (Bekaroğlu, 2014), disiplinin kurucu jenerasyonunun Türk coğrafya pratiğini tesis etmeye başlamasından göreceli olarak kısa bir süre sonra, yani İkinci Dünya Savaşı'nın ertesinde modern coğrafya dönemi sona ermeye başlamıştır. Bu bakımdan Türk coğrafyacılığının inşası, Batı coğrafyacılığının modern döneminin sonlarında gerçekleşmeye başlamıştır ve çok kısa bir süre sonra coğrafyada hem eksenel (Kıta Avrupası okullarının hakimiyetinden Anglo-Amerikan okullarının hakimiyetine) hem de niteliksel [tek kültürcü modern dönem pratiğinden iki kültürcü çağdaş pratiklere (Bekaroğlu, 2016)] bir değişim yaşanmıştır. Tüm bunların başladığı ve olgunlaştığı periyotta, AngloAmerikan coğrafyacılığına pek de tanıdık olmayan ve de disiplinin varlık sebebine dair herhangi bir sorunsalı bulunmayan Türk coğrafyacılığının kurumsal inşası enerjik bir biçimde devam etmekteydi. Bu minvalde değerlendirildiğinde, Türk coğrafyacıllğındaki Kıta Avrupası terbiyesi almış olan kurucu (üçüncü) jenerasyonun disiplin üzerindeki hakimiyeti (ve ardışık olarak yetiştirdiği kuşakların etkisi), Türk coğrafyacıllı̆ının holistik düsturunda bir tür yol bağımlılığına imkan sağlamış gibi görünmektedir; öyle ki, disiplinin kabuk değiştirmesi (yani, anti-holistik pratiklerin sistematik olarak baş göstermesi) belki de biraz da bu türlü bir etkiyle yaklaşık olarak yarım yüzyıl ötelenmiş olabilir.

Türk coğrafya pratiğinin, sahip olduğu ontolojik kabüllerini sorgulayıp değiştirmeye başlamasının miladı 2000'li yılların ilk yarısına rastlamaktadır. Bu gözlemi mümkün kılan (ve bu bağlamda bu çalışmadaki jenerasyonel bağlamla ilişkilendirilmesi gereken) ampirik kanıtlar, bu son 15 yıllık değişim döneminde Türk coğrafyacılığında Anglo-Amerikan coğrafya okullarının etkisinin hissedildiğini (Bekaroğlu ve Yavan, 2013), uluslararası yayın performansının arttığını (Bekaroğlu ve Sarış, 2017; Yavan, 2005a; 2019) ve farklı disiplinlerle diyaloğun güçlendiğini (Yazan ve Bekaroğlu, 2018) açık bir şekilde göstermektedir. Ayrıca, sözü edilen bu dönemde disiplin içerisinde bir "yeni arayış"ın ve değişim talebinin yankısı, birbirinden farklı bağlamlarda olmak üzere literatüre de yansımış durumdadır (örn. Ar1, 2005, 2013; Arı ve Köse, 2005; Bekaroğlu, 2016; Bekaroğlu ve Özdemir, 2014; Bekaroğlu ve Yavan, 2018; Bilgili, 2017; Kaya, 2005; 2010; Kaygalak, 2011; Kervankıran ve Şardağ, 2019; Özgür ve Yavan, 2013; Tuysuz ve Yavan, 2012; Yavan, 2005b). Birbirinden farklı içsel ve dışsal faktörlere (örn. Bekaroğlu ve Yavan, 2013; Özgür ve Yavan, 2013) bağlı olarak ortaya çıkan ve bilim yapma pratiğine de yansımaya başlamış olan bu değişen disipliner pratiğin karakteristik aktörleri esas olarak 16-18. jenerasyonun üyesidir. Bunun yanı sıra, bilim yapma pratiğinde değişim yaratarak disipliner dönüşüme katkı sağlayan daha olgun bazı aktörlerin varlığı da söz konusudur ki, bunlar da temel olarak 14. ve 15. jenerasyonun üyesi durumundadır ${ }^{6}$.

Bu bakımdan, Türk coğrafyacılığındaki değişimin aktörleri üzerine yapılan güncel bir çalışma (Özgür, 2018) bağlamında, beşeri coğrafya özelinde olmak üzere, Türk coğrafyacılığındaki, AngloAmerikan coğrafya okulları ve bu okulların etkisi altındaki yerlerde lisansüstü eğitim almış olan bir dizi aktör ile yerelde değişimi kendi girişimleriyle deneyimlemeye çalışan diğer bir dizi aktör (Arı, 2019), disiplindeki değişimin atılımcıları ve/veya erken benimseyenleri olarak kabul edilebilir ki, bu aktörlerin tümü, yukarıda işaret edildiği gibi, değişen ağırlıklarda son beş jenerasyonun üyeleri arasında yer almaktadır.

Aynı çalışmada (Özgür, 2018) ayrıca, genç akademisyenlerin yenileşme süreçlerine ilişkin deneyimleri de bir model halinde sunulmuştur. Söz konusu modelin temel parametreleri bilgi edinme, farkındalık ve ikna olma, benimseme, gerçekleştirme ve onay olarak etiketlenmiştir. Bu model 
lisansüstü eğitim alan aktörlerin deneyimi üzerinden yapılandırıldığından, Türk coğrafyacıllı̆̆ında beliren yenileşme eğiliminin devamlılığı açısından lisansüstü eğitimin önemini bu noktada artırmaktadır. Bu bağlamda, günümüzde lisansüstü eğitimin ve dolayısıyla doktorant yetiştirme sürecinin 7 kuşaklık bir aralıkta sürdürülmesi önemlidir. Zira, 9. kuşağa kadar nispeten homojen bir jenerasyon tarafından yetiştirilen kuşakların tersine, günümüzde disipliner yeniden-üretim sürecinde heterojen bir jenerasyon topluluğu rol oynamaktadır ve bu bakımdan yetiştirici kuşak genişliği 7 jenerasyona varmaktadır. Kuşkusuz, Türk coğrafyacılığındaki değişimin devamlılığı açısından bu heterojen yapı -farklılıkların kendisini ifade edebilmesi açısından- potansiyel bir imkanı da içerisinde barındırmaktadır.

Ne ki, disiplindeki geleneksel ve çağdaş yönelimlerin günümüzde sahip olduğu simbiyotik ilişkinin (Bekaroğlu ve Yavan, 2018), bu çalışmada ortaya konan jenerasyonel ritm göz önüne alındığında -sosyal süreçlerin açık sisteme sahip yapısının ihtiyatlılığı çerçevesinde olmak üzeredisiplin içerisinde nispeten uzun bir süre devam edeceği de beklenmelidir.

\section{Notlar}

${ }^{1}$ Kuşkusuz, kohort nosyonuna bağlı olarak yapılan bu ayrıma ilişkin iki temel noktanın altı çizilmelidir: Bunlardan birincisi, kohortlara ilişkin kavrayışın zaman içerisinde anlam kazanmasıdır. Örneğin, bu çalışmada 3. jenerasyon olarak etiketlenen kuşağın etkin olduğu dönemde, söz konusu kohortu oluşturan bireyler arasında pek çok farklılık pekala ayırt edilebilirdi. Lakin, günümüzden bakıldığında bu kuşağın en önemli (ortak) hususiyetinin Kıta Avrupasındaki coğrafya okullarında okumaları, birbirine az çok benzer bir epistemolojiye sahip bireylerden oluşmaları ve Türkiye'deki coğrafyacılık pratiğini kurumsallaştırmış olmaları olduğu belirlenebilmektedir. Söz konusu tarihsel kavrayış, güncel kohortlara doğru gelindiğinde giderek muğlaklaşmakta ve farklılıklar daha baskın hale gelmektedir. Ne ki, aslında bu güncel kohortlar da zaman içerisinde daha berrak bir anlama sahip olacaklardır. Bununla ilintili olarak belirtilmesi gereken ikinci husus ise, aynı kohort içerisinde yer alanların mutlak olarak benzer bir düşünce modu ortaklığı ve benzer bir disipliner aktivite örüntüsü sergilemesinin her zaman mümkün olmayabileceğidir. Bu nedenle, aynı jenerasyonda yer almalarına rağmen dikkat çekici bir şekilde farklı pratikler gösterenlerin birbirlerine göre aynı jenerasyonun farklı birimlerini oluşturduğu hususu göz önüne alınmalıdır.

${ }^{2}$ Kurucu bilimciler, Coğrafya Darülmesaisi'ndeki müderrisler, Ankara ve İstanbul üniversitelerinde çalışan yabancı bilimciler ile eğitimlerini 1920-1930'lu yıllarda Kıta Avrupası'nda yapan Türk coğrafyacılarından oluşmaktadır.

${ }^{3}$ Jenerasyonlar, disiplinin sistematik olarak doktoralı profesyonel coğrafyacılar üretmeye başladığı dönemdeki disipliner yeniden-üretim sürecini ifade etmektedir. Bu süreç, 4. jenerasyonla başlamıştır ve halen devam etmektedir. Bununla birlikte, bu süre zarfında (1943-2014) 26 coğrafyacı doktora derecesini yurt dışından almıştır.

${ }^{4}$ Kuşkusuz, jenerasyon birimleri, esasında her bir farklı lokasyondaki üniversiter yeniden-üretim sürecinde ve hatta aynı birimdeki farklı bireyler arasında da ayırt edilebilir. Çalışmada, genel örüntüyü ortaya koymak bakımından, jenerasyon birimleri merkez-çevre üniversiteler bazında soruşturulmuştur.

${ }^{5}$ Gerçekten, 3. jenerasyonun akademik coğrafya dergilerindeki yayınlarında, Osmanlı dönemi başta olmak üzere, kendilerinden önceki -coğrafya olarak nitelendirilebilecek olan- yayınlara atıf oranı \% 3.5 'tir.

${ }^{6}$ Türk coğrafyacılığında yenilik girişimleri tarihsel olarak ele alındığında sadece burada anılan beş jenerasyonla sınırlı değildir. Lakin, örneğin özellikle 9-10. jenerasyonun bazı üyeleri gibi, geçmişte disipliner pratikte çağdaş yönelimlere yakınsak etkinliklerde bulunmuş olan aktörlerin yenilikçi eğilimleri, makro açıdan değerlendirildiğinde artımlı bir jenerasyonel devamlılık sergilememiştir. Bu, yani yeniliğin kuşaklararası artımlı devamlılı̆̆ı, önceki iki jenerasyonun bazı üyelerini de kapsamak üzere esas olarak 16-18. jenerasyonlarda yoğunlaşan bir özelliktir. Bu son dönemdeki yenilik arayışlarının bir diğer ayırt edici özelliği ise, yeniliğe ilişkin talep ve eleştirinin literatüre yansımış olmasıdır.

\section{Teșekkür}

Bu çalışmanın erken aşamalarında yaptığı katkılardan dolayı E. Murat Özgür'e, makalenin hakemlerine ve yayın aşamasındaki yardımlarından dolayı Kerime Karabacak'a teşekkür ederiz. Çalışma, TÜBİTAK 114K063 numaralı proje tarafından desteklenmiştir. 
To cite: Bekaroğlu, E., Yavan, N., Anlı, Ö.F. (2019). Generations in Turkish Geography: A Cohort Approach to the History of the Discipline, Coğrafi Bilimler Dergisi/ Turkish Journal of Geographical Sciences, 17(1), 55-77, doi: 10.33688/ aucbd.502638

$\begin{array}{ccc}\text { Coğrafi Bilimler Dergisi } & \text { Cografi } \\ \text { Bilimler } \\ \text { Dergisi }\end{array}$

\section{Generations in Turkish Geography: A Cohort Approach to the History of the Discipline}

Erdem Bekaroğlu*a ${ }^{*}$ Nuri Yavan ${ }^{\mathrm{b}}$, Ömer Faik Anl ${ }^{\mathrm{c}}$

Submitted: 25.12 .2018

Accepted: 28.02 .2019

\section{EXTENDED ABSTRACT}

\section{Introduction}

Knowledge transfer is a complex process that is carried out using a wide range of media platforms and is mainly dependent on generational continuity. In this respect, academic and scientific knowledge production, which has gained an institutional identity within the university system since the $19^{\text {th }}$ century (Wallerstein, 2014) has been subjected to the generational transfer of knowledge. When considered in terms of geography, which was established as a university discipline in Pan-European countries during the second half of the $19^{\text {th }}$ century (Unwin, 1992), institutionalization and reproduction of geographical knowledge in Turkey commenced in the first quarter of the $20^{\text {th }}$ century, through the efforts of foreign academics and Turkish geographers who graduated from geography schools of universities in Continental Europe (Erinç, 1973; Tümertekin, 1971).

In this study, scholars in Turkish geography have been subjected to a generational analysis, the results of which have been examined temporarily and spatially according to various parameters. This initiative, which reflects an exploratory research practice, aims to illuminate the historicity of the discipline from a different perspective by dividing Turkish geographers into generations through a cohort approach. In this respect, the study examines the long-term temporal-spatial tendencies of generations in an empirical-analytical way rather than the social relations between the generations, and thus constitutes another pillar of the studies examining Turkish geography in recent years with a similar methodology (e.g. Bekaroğlu ve Sarış, 2017; Bekaroğlu ve Yavan, 2013; 2018; Yavan, 2005; 2019; Yazan ve Bekaroğlu, 2018).

The study consists of four parts. The introduction of the background of the study is followed by how the generation theory is operationalized and what sort of the data sources used in the study are included in the method section. The study continues with the third section where the results are examined. The fourth part is the discussion of the results in light of the historical development of Turkish geography.

\section{Method}

The generation is basically a group of individuals that come together in social cohesion. This common ground reflects a chronological homogeneity, which is determined by the rhythm of biological

\footnotetext{
*Corresponding Author: ebekaroglu@ankara.edu.tr

a Ankara Üniversitesi, Coğrafya Bölümü, Ankara, Türkiye, https://orcid.org/0000-0003-0920-9225

b Ankara Üniversitesi, Coğrafya Bölümü, Ankara, Türkiye, https://orcid.org/0000-0002-6752-6598

c Ankara Üniversitesi, Felsefe Bölümü, Ankara, Türkiye, https://orcid.org/0000-0002-5621-5145
} 
existence. In this respect, those in the same generation, i.e. those born in the same/similar year(s), are connected to a common location in the historical dimension of the social world (Mannheim, 1952). Therefore, they share a certain type of behavior, emotion and mode of thought, apart from individual differences.

Since there is a commonality in the chronological location at the core of the generation theory, certain difficulties arise in the division of passive and active actor groups, when this notion is applied to the history of a discipline. Due to some of these difficulties such as the distinction made by the years of birth and the master-pupil relationships, a cohort approach (Glenn, 2005) has been used to divide Turkish geography into generations.

Doctoral education, regardless of the birth year or master-pupil chain, has been used to divide scholars in Turkish geography into different generations. The process of doing a doctorate, which generally takes between 4 to 6 years, has been taken as a standard 5 year-period. Those who have completed doctoral studies in each of the 5-year periods have been classified under the same cohort. According to this classification, cohorts have been labeled or numbered starting from the oldest to the newest such as $1^{\text {st }}$ generation, $2^{\text {nd }}$ generation, etc., as well as the year from mid-point of the 5-year period (e.g. 1957 generation, from 1955 to 1959). Those who were active in the discipline prior to doctorate education were labeled as "founding" generations and grouped in 10-year intervals based on the periods that they were active.

The data series of doctoral dissertations covering the years between 1943 and 2014 were obtained from four different sources: the first one is the YÖK (Council of Higher Education) National Thesis Center database (YÖK, 2018). The second data source is Istanbul University Central Library (IÜMK, 2015). Third one is Ankara University, Faculty of Languages, History and Geography Library (AÜDTCF, 2015). The last data source consists of the records of 26 geographers who obtained their Ph.D. from abroad (Yurtdışı, 2017).

The tendencies of the generations that have been active in Turkish geography until the present are examined under seven categories: the number of members in each generation, dominant generations, the distance of dominant generation to developed generation, the most distant generation difference, the closest generation difference, the relationship between the number of members and productivity, the temporal change of the productivity performance of the dominant generations.

\section{Results}

Turkish geography, as an academic discipline, is characterized by a total of 18 generations from the beginning to the present day (Table 1). The first three generations of the series are composed of founding scientists $(n=15)$ and the remainder consists of the generations raised $(n=409)$.

Generations in Turkish geography are represented by 7 people on average between $3-13^{\text {th }}$ generations, and this ratio rises to 66 between $14-18^{\text {th }}$ generations. In this respect, growth in Turkish geography began mainly with the $14^{\text {th }}$ generation (Figure 1a). In terms of all generations, the dominant generations in Turkish geography are as follows (Figure 1b): $3^{\text {rd }}$ generation, $4^{\text {th }}$ generation, $8^{\text {th }}$ generation, $9^{\text {th }}$ generation, $11^{\text {th }}$ generation, $14^{\text {th }}$ generation. 
Table 1. Generations in Turkish Geography

\begin{tabular}{|c|c|c|c|c|c|c|c|c|c|c|c|c|c|c|c|c|c|}
\hline \multicolumn{3}{|c|}{ Founders } & \multicolumn{15}{|c|}{ Generations } \\
\hline 1915 & 1925 & 1935 & 1942 & 1947 & 1952 & 1957 & 1962 & 1967 & 1972 & 1977 & 1982 & 1987 & 1992 & 1997 & 2002 & 2007 & 2012 \\
\hline 1 & 2 & 3 & 4 & 5 & 6 & 7 & 8 & 9 & 10 & 11 & 12 & 13 & 14 & 15 & 16 & 17 & 18 \\
\hline 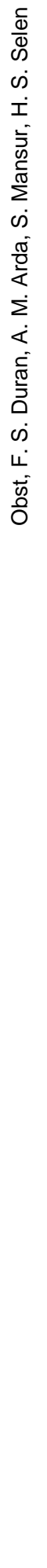 & 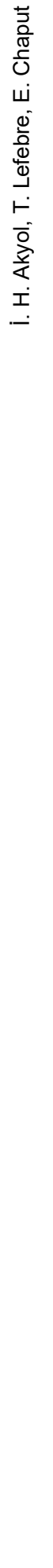 & 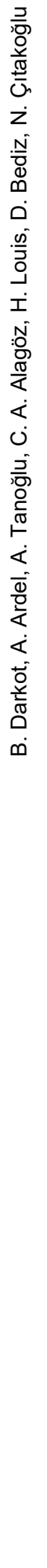 & 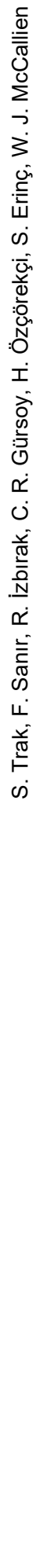 & 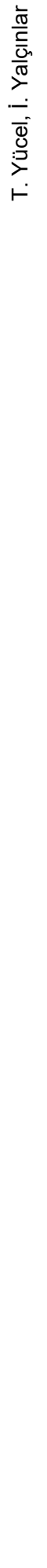 & 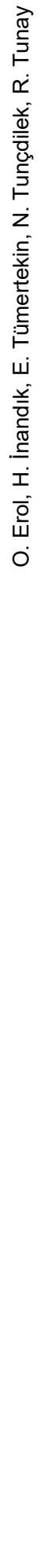 & 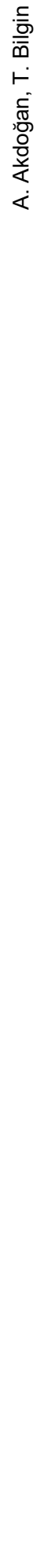 & 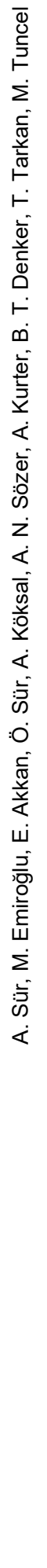 & 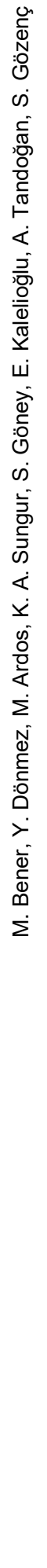 & 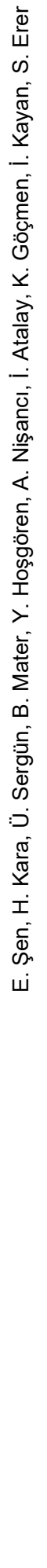 & 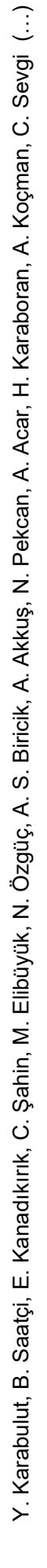 & 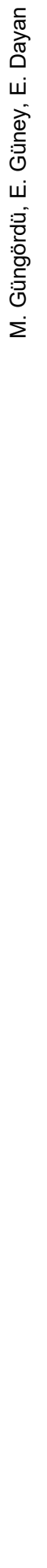 & 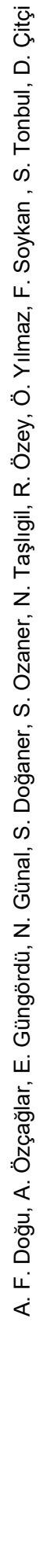 & 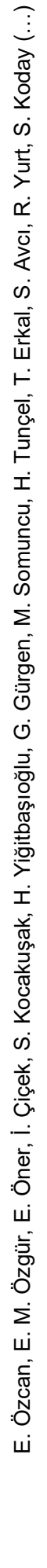 & 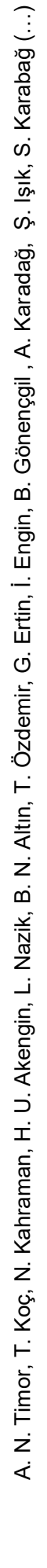 & 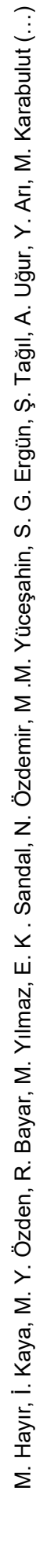 & 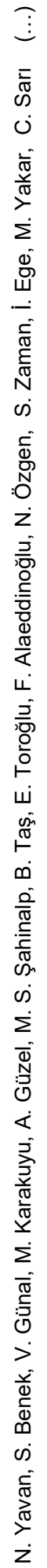 & 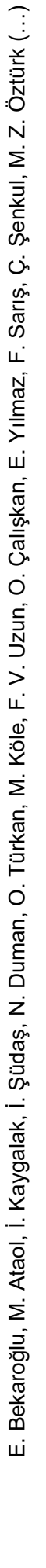 \\
\hline
\end{tabular}



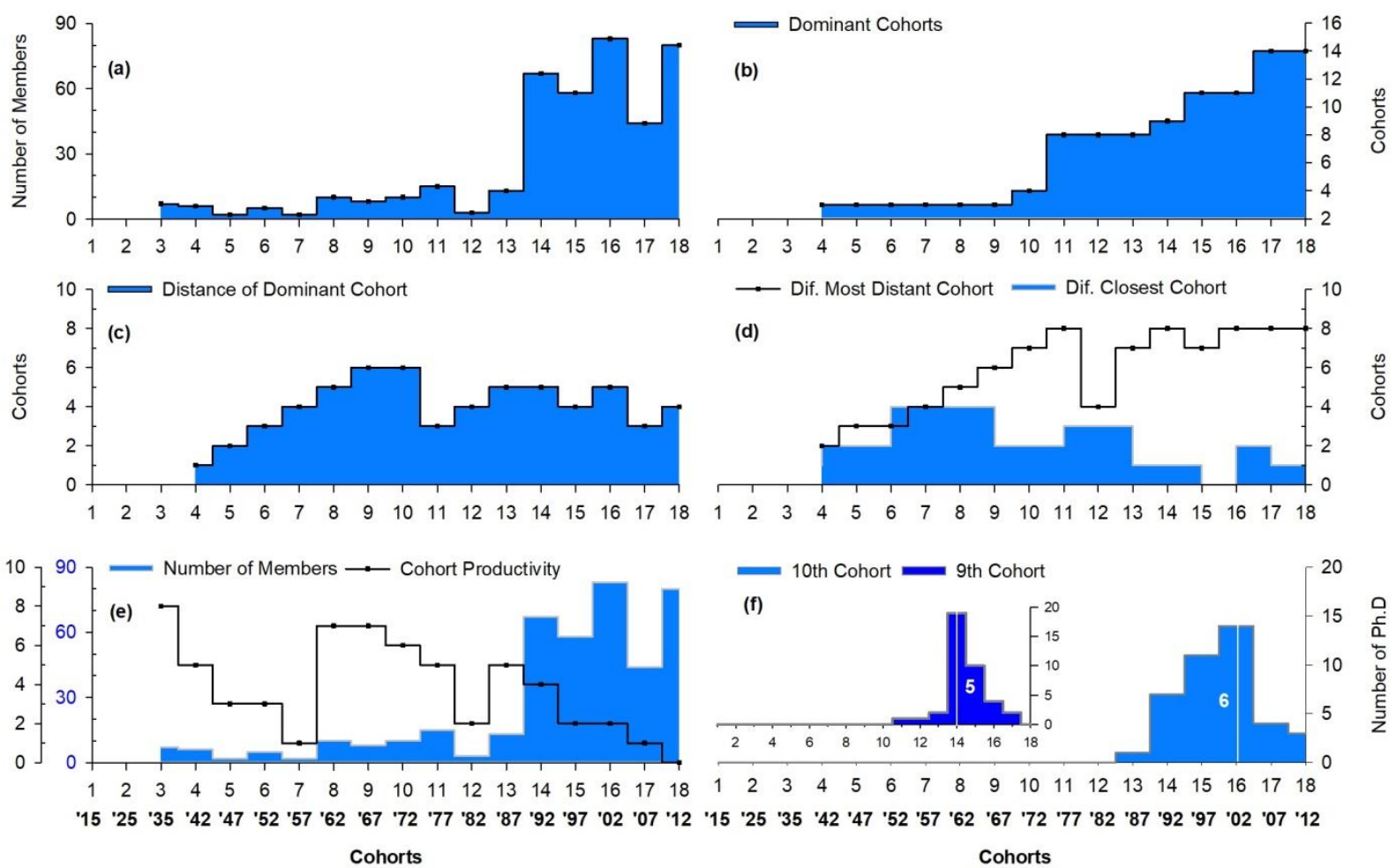

Figure 1. The temporal tendencies of generations in Turkish geography.

The most influential actors in the discipline are members of the $3^{\text {rd }}, 8^{\text {th }}, 11^{\text {th }}$, and $14^{\text {th }}$ generations, however. Of these, it is noteworthy that the $3^{\text {rd }}$ generation played a dominant role in producing the next six generations.

When it is looked at the distance of the dominant generation to the generation it produces, it is observed a tendency to move away from the $4^{\text {th }}$ generation to the $10^{\text {th }}$ generation (Figure $1 \mathrm{c}$ ). The distance of the dominant generation, which started to show a convergent trend with the $11^{\text {th }}$ generation, has a mean of 4 generations since the $12^{\text {th }}$ generation. When the temporal pattern of the difference between the closest generation and the most remote generation is evaluated (Figure 1d), it becomes evident that these differences are minimal until the $9^{\text {th }}$ generation, and that the pattern has started to increase after the $12^{\text {th }}$ generation. There is no linear relationship between the number of members of each generation and the number of scholars trained by this generation in the field of Turkish geography. The productivity (in terms of the number of Ph.D. graduates) of a generation in Turkish geography is limited to 8 generations. Considering the generations that contributed to the production of $\geq 6$ generations in the discipline, it can be observed that the performance of the generations was maximized with the $5^{\text {th }}$ or $6^{\text {th }}$ generation.

As disciplinary reproduction processes in Turkish geography have not been realized in a single place and because the production in question has spread to the universities in the periphery (the universities apart from Istanbul University and Ankara University) since the end of the 1970s, different generation units have emerged in the discipline. Central universities fully dominated the disciplinary reproduction process until the $10^{\text {th }}$ generation (Figure 2a). Universities in the periphery, however, were included in the process by the $11^{\text {th }}$ generation, but mainly by the $13^{\text {th }}$ generation. In this period, geographers received degrees from 13 different departments (and also from various universities abroad). 
$42 \%$ of the doctoral degrees obtained from universities in periphery belong to Atatürk University, $17 \%$ to Frrat University, $11.5 \%$ to Marmara University, $8.5 \%$ to Ege University and $5.7 \%$ to 9 Eylül University (Other: $15.5 \%$ ). In terms of the number of members of the generations, the quantitative superiority of central universities between the $10-14^{\text {th }}$ generations has changed by the $15^{\text {th }}$ generation (Figure 2a).
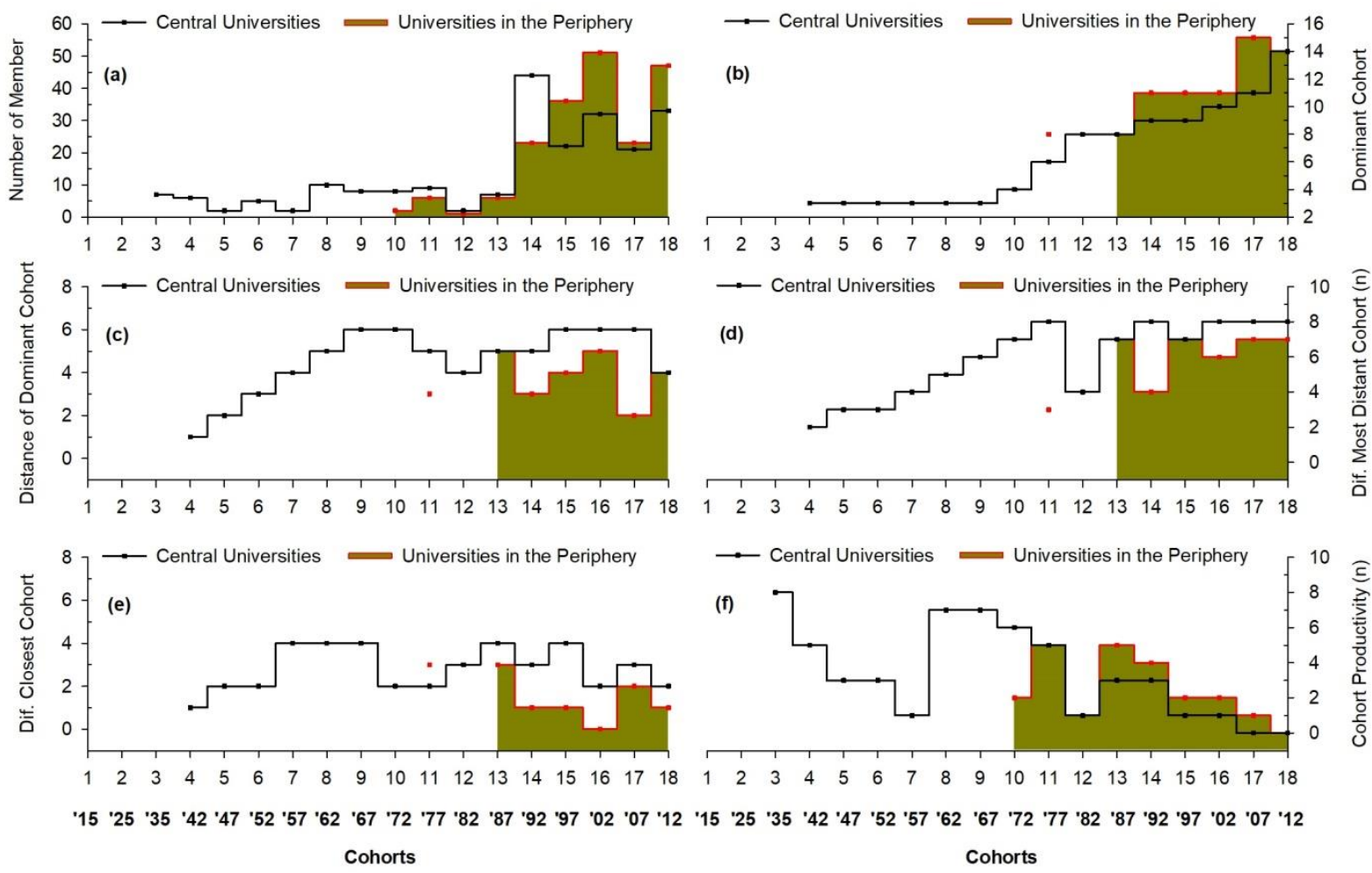

Figure 2. The temporal tendencies of generations in central universities and universities in the periphery.

In this regard, universities in the periphery are more efficient in the production of the last 4 generations. The dominance of the $8^{\text {th }}, 11^{\text {th }}, 14^{\text {th }}$, and $15^{\text {th }}$ generations comes to the fore in the disciplinary reproduction processes at the universities in the periphery (Figure 2b). Another characteristic is that the dominant generations at the universities in the periphery are generally characterized by younger groups of scholars than their counterparts in central universities. However, the dominant generations in the central universities with the dominant generations at the universities in the periphery have been equalized in the last generation. Considering the distance of the dominant generation to the generation produced, the generations produced in central universities consist of more mature groups (Figure 2c). In the central universities, it is also observed that older generations are more active in the training processes than the universities in the periphery (Figure 2d). However, this difference has been closed and became stable in the last two generations. The difference of the nearest generations to the raised cohorts in the central universities is different from the pattern observed in the universities in the periphery. There has been a tendency to rejuvenate gradually in the latter (Figure 2e). Considering the central-periphery dichotomy, it is observed that the productivity of the latter has become higher by the $13^{\text {th }}$ generation (Figure 2f). The members of the currently active generations in the universities in the periphery have a share in producing more generations. 


\section{Discussion and Conclusion}

A number of fundamental conclusions can be underlined by the generational composition of Turkish geography. The first one is that Turkish geography experienced a generational maturity period until the $9^{\text {th }}$ generation. Second, the number of members of generations in Turkish geography increased with the $14^{\text {th }}$ generation. The third is the lack of a linear relationship between the number of members of a generation and the productivity of that generation. Fourth, the generations of the universities in the periphery in the academic reproduction processes experienced a maturation process over time.

After these general evaluations, it has to be focused on two different aspects of the generational context of Turkish geography. First is that the $3^{\text {rd }}$ generation's dominant role in the production of the next 6 generations and the second is the generational context of the innovation processes that the discipline has been experiencing since the first half of the 2000s.

The members of the group labeled as $3^{\text {rd }}$ generation in Turkish geography (B. Darkot, A. Ardel, A. Tanoğlu, C. A Alagöz, D. Bediz, N. Çıtakoğlu, and also İ. H. Akyol), were educated abroad (mainly in France, Germany, Switzerland and Austria) in the 1920s and 1930s with the opportunities provided by the newly established Republic of Turkey (Erinç, 1973; Tümertekin, 1971), and after the 1933 university reform (Günergun, 2010), they have taken part in the geography departments of two (central) universities in the country. Therefore, the members of this generation can be considered as founders of modern geography in Turkey. The $3^{\text {rd }}$ generation in Turkish geography played a dominant role in the production of the next six generations from the 1940s. This is a feature that can only be seen in a newly established discipline by a relatively young generation. In this period where there was no conflict on the ontology of the discipline, their holistic understanding of geography should have determined the scientific practice. This composition may be one of the fundamental dynamics in the rooting of the strong holistic structure of Turkish geography. The dominance of the founding (third) generation on the discipline (and the effect of the generations it has grown in succession) seems to have enabled a kind of path dependency in the holistic motto of Turkish geography for a long time, which, perhaps, may have retarded the restructuring of the discipline by about half a century.

The milestone of Turkish geography practice in questioning its ontological assumptions coincides with the first half of the 2000s. The empirical evidence that makes this observation possible (and should be related to the generational context in this study) suggests that the impact of the AngloAmerican geography schools in Turkish geography has been felt for the last 15 years (Bekaroğlu and Yavan, 2013), that the international publication performance increased (Bekaroğlu and Sarış, 2017; Yavan, 2005a; 2019) and the dialogue with different disciplines have been strengthened (Yazan and Bekaroğlu, 2018). In addition, the echo of a demand for change in the discipline has been reflected in the literature in different contexts as well (e.g. Ar1, 2005, 2013; Arı ve Köse, 2005; Kaya, 2005; 2010; Yavan, 2005b; Kaygalak, 2011; Tuysuz ve Yavan, 2012; Özgür ve Yavan, 2013; Bekaroğlu ve Özdemir, 2014; Bekaroğlu, 2016; Bilgili, 2017; Bekaroğlu ve Yavan, 2018; Kervankıran ve Şardağ, 2019). Characteristic actors of this changing disciplinary practice, which have emerged in connection with different internal and external factors (e.g. Bekaroğlu and Yavan, 2013; Özgür and Yavan, 2013) and have begun to reflect on scientific practices, are mainly members of the $16-18^{\text {th }}$ generation. In addition, there are some other mature actors, who contribute to the disciplinary transformation by changing their scientific practice, and they are among the members of the $14^{\text {th }}$ and $15^{\text {th }}$ generations. In this respect, a 
number of academics who have done postgraduate studies in Anglo-American geography schools (Ar1, 2019) and a number of others who try to experience the change at the local level can be considered as the innovators and/or early adopters of change in the discipline (Özgür, 2018).

However, it should also be expected that the symbiotic relationship of traditional and contemporary orientations in the discipline (Bekaroğlu and Yavan, 2018) will continue for a relatively long time in the discipline, given the generational rhythm presented in this study.

\section{Referanslar}

Akyol, İ. H. (1943). Son Yarım Asırda Türkiye'de Coğrafya I: Mutlakiyet Devrinde Coğrafya, Türk Coğrafya Dergisi, 1, 315.

Anlı, Ö. F. (2016). Bilim Savaşları: Modern Bilim İmgesinin Dönüşümü. Ankara: Phoenix.

Arı, Y. (2002). Amerika Birleşik Devletleri'nde Coğrafya Eğitimi Reformu: Türkiye için Dersler, Türk Coğrafya Kurumu, Coğrafya Kurultayı, Bildiriler Kitabı içinde (s.140-147). Ankara: Gazi.

Arı, Y. (2005). 20. Yüzyılda Amerikan Coğrafyası: Genel Bir Değerlendirme, Y. Arı (Ed.). 20. Yüzyllda Amerikan Coğrafyasının Gelişimi içinde (3-19). Konya: Çizgi.

Arı, Y. (2013). Yeni yüzyılda Türkiye'de Coğrafya: Fırsatlar ve Tehditler, Beşeri Coğrafya Dergisi, 1, 6-13.

Arı, Y. (2019). Yenilik ve Bilimsel Gelişme: Türk Coğrafya Tartı̧̧ma Listesinin (Coğrafya) İçerik Analizi (1997-2012), International Journal of Geography and Geography Education, 39, 95-120.

Arı, Y., Köse, A. (2005). İnsan-Çevre Etkileşimini Yorumlamada Yeni Bir Alternatif: Kültürel Coğrafya. Ulusal Coğrafya Kongresi 2005 (Prof. Dr. Ísmail Yalçınlar Anısına), Bildiriler Kitabı içinde (51-59). İstanbul: Türk Coğrafya Kurumu.

AÜDTCF, (2015). Katalog Tarama. Ankara: Ankara Üniversitesi Dil ve Tarih-Coğrafya Fakültesi Kütüphanesi.

Bekaroğlu, E. (2014). Modern Türk Coğrafyası Geleneği. E. Bekaroğlu, A. R. Özdemir (Ed.). Bir Disiplinin İ̧ Dünyası: Modern Türk Coğrafyası Üzerine Söyleşiler içinde, (53-69), İstanbul: İdil.

Bekaroğlu, E. (2016). Modern Dünya-Sisteminin Bilgi Yapıları Bağlamında Coğrafya İçin Bir Dışsal Tarih Okuması, Toplum ve Bilim, 136, 117-146.

Bekaroğlu, E., Yavan, N. (2013). Modern Türk Coğrafyasının Tarihsel Gelişiminde Batılı Coğrafya Okullarının Etkisi: Ampirik Bir Analiz, Beşeri Coğrafya Dergisi, 1, 51-66.

Bekaroğlu, E., Özdemir A. R. (Ed.). (2014). Bir Disiplinin İç Dünyası: Modern Türk Coğrafyası Üzerine Söyleşiler. İstanbul: İdil.

Bekaroğlu, E., Sarış, F. (2017). Türkiye'de Fiziki Coğrafya: Değişen Disiplinler Pratiğin Ampirik Bir Analizi, Marmara Coğrafya Dergisi, 35, 40-54.

Bekaroğlu, E., Yavan, N. (2018). Türk Coğrafyacıllı̆ında Dört Gelenek: Ampirik Bir Analiz, Marmara Coğrafya Dergisi, 37, 79-93.

Bilgili, M. (2017). Coğrafyanın Bilimsel Kimliğine Postyapısalcı Bir Yaklaşım, Marmara Coğrafya Dergisi, 35, 101-109.

Collins, R. (1998). The Sociologies of Philosophies: The Global Theory of Intellectual Change. MA: Harvard University Press.

Darkot, B. (1951). Türkiye Coğrafyasının Kuruluşuna Bir Bakış, İstanbul Üniversitesi Coğrafya Enstitüsü Dergisi, 1, 59-62.

Dickinson, E. R. (1969). The Makers of Modern Geography. London: Routledge and Kegan Paul.

Erinç, S. (1973). 50 Yılda Coğrafya. Ankara: Başbakanlık Kültür Müsteşarlığı, Cumhuriyetin 50. Yıldönümü Yayınları.

Glenn, N. D. (2005). Cohort Analysis. Sage: London.

Gümüşçü, O., Özür, N. K. (2016). Türkiye'de Modern Coğrafyanın Kuruluşu Ve Örgütlenmesi (1915-1941), Atatürk Araștırma Merkezi Dergisi, 93, 105-147.

Günergun, F. (2010). İstanbul Üniversitesi Edebiyat Fakültesinde Araştırmanın Kurumsallaşması: 1933 Reformunu İzleyen Otuz Yı1 İçinde Yapılan Doktoralar, N. K. Aras, E. Dölen, O, Bahadır (Ed.), Türkiye 'de Üniversite Anlayışının Gelişsimi (1861-1961) içinde (s. 190-213), Ankara: TÜBA.

İÜMK, (2015). Katalog Tarama. İstanbul: İstanbul Üniversitesi Merkez Kütüphane.

Johnston, R. J. (2017). Beşeri Coğrafya: Değişen Disipliner Gündemin Politiği, Çev. Erdem Bekaroğlu, Posseible, 10, 39-57. 
Kaya, İ. (2005). Sosyal Teori ve Beşeri Coğrafya. Ulusal Coğrafya Kongresi 2005 (Prof. Dr. İsmail Yalçınlar Anısına) Bildiriler Kitabı içinde (257-266). İstanbul: Türk Coğrafya Kurumu.

Kaya, İ. (2010). Değişen Sosyal ve Bilimsel Bağlam ve Coğrafyanın Sorumlulukları, R.Özey ve S.İncekara (Ed.). Coğrafya Eğitiminde Kavram ve Değişimler içinde (s.227-242), Ankara: Pegem.

Kaygalak, İ. (2011). Postmodern Eleştirilerin Coğrafi Düşünce ve Yeni Mekân Kavrayışları Üzerine Yansımaları, Coğrafi Bilimler Dergisi, 9, 1-10.

Kervankıran, İ., Şardağ, A. (2019). Türkiye'de Turizm Coğrafyası Araştırmaları: Lisansüstü Tezlere Yönelik Bir İçerik Analizi, International Journal of Geography and Geography Education, 39, 151-170.

Kuhn, T. S. (2006). Bilimsel Devrimlerin Yapısı. Çev. Nilüfer Kuyaş, İstanbul: Kırmızı.

Mannheim, K. (1952). The Problem of Generations, P. Kecskemeti (Ed.), Essays on the Sociology of Knowledge içinde (276320), London: Routledge and Kegan Paul.

Özgür, E. M. (2018). Türk Beşeri Coğrafyasında Yenileşme Eğilimleri: Değişim Aktörlerinin Perspektifinden Bir Değerlendirme, International Journal of Geography and Geography Education, 38, 142-170.

Özgür, E. M., Yavan, N. (2013). Türk Coğrafyacılarının İç Hesaplaşması: Neden Başaramadık? Nasıl Başarabiliriz?, Beşeri Coğrafya Dergisi, 1, 14-38.

Tekeli, İ. (2010). Mekânsal ve Toplumsal Olanın Bilgibilimi Yazıları. İstanbul: Tarih Vakfı Yurt Yayınları.

Tuysuz, S., Yavan, N. (2012). Bölgesel Coğrafya Yaklaşımı ve Türk Coğrafyasındaki Etkileri Üzerine Kritik Bir Değerlendirme, TÜCAUM VII. Coğrafya Sempozyumu, Bildiriler Kitabı içinde (s. 390-405), Ankara: TÜCAUM.

Tümertekin, E. (1971). Türkiye'de Beşeri Coğrafyanın Gelişmesi. E. Tümertekin, F. Mansur ve P. Benedict (Eds). Türkiye: Coğrafi ve Sosyal Araştırmalar içinde (s. 1-16), İstanbul: İstanbul Üniversitesi Edebiyat Fakültesi Yayınları.

Unwin, T. (1992). The Place of Geography. Essex: Prentice Hall.

Wallerstein, I. (2014). Modern Dünya Sistemi 4: Merkezci Liberalizmin Zaferi 1789-1914. İstanbul: Yarın.

Yavan, N. (2005a). SCI ve SSCI Bağlamında Türkiye'de Coğrafya Biliminde Uluslararası Yayın Performansının Karşılaştırmalı Analizi: 1945-2005, Coğrafi Bilimler Dergisi, 3, 27-55.

Yavan, N. (2005b). Bilim Felsefesi Bakımından Coğrafyada Pozitivist Yaklaşım. Ulusal Coğrafya Kongresi 2005, Bildiriler Kitabı içinde (405-414), İstanbul: Türk Coğrafya Kurumu.

Yavan, N. (2012). Postgraduate Geography Education in Turkey. N. Yavan ve İ. Kaya (Ed.), International Perspectives on Postgraduate Education and Training in Geography içinde (s. 111-157), Diyarbakır: Turkish Association of Geographers Publications.

Yavan, N. (2019). Türkiye'deki Coğrafyacıların Uluslararası Yayın Performansı (1945-2015): Son 10 Yılda (2005-2015) Ne Değişti? International Journal of Geography and Geography Education, 39, 121-150.

Yazan, S., Bekaroğlu, E. (2018). Türk Coğrafyacılığının Disipliner İlişkileri Üzerine Ampirik Bir Araştırma, Coğrafi Bilimler Dergisi, 16, 37-67.

YÖK, (2017). YÖK Ulusal Tez Merkezi Veri Tabanı. https://tez.yok.gov.tr/UlusalTezMerkezi. Son erişim 31 Ağustos 2017

Yurtdışı, (2017). Katalog Tarama. Almanya, Fransa, İngiltere ve ABD’nin Milli Kütüphaneleri ile İlgili Üniversitelerin Kütüphaneleri. 
EK 1. Türk Coğrrafyacilı̆ı̆ndaki Jenerasyonlar (tam liste)

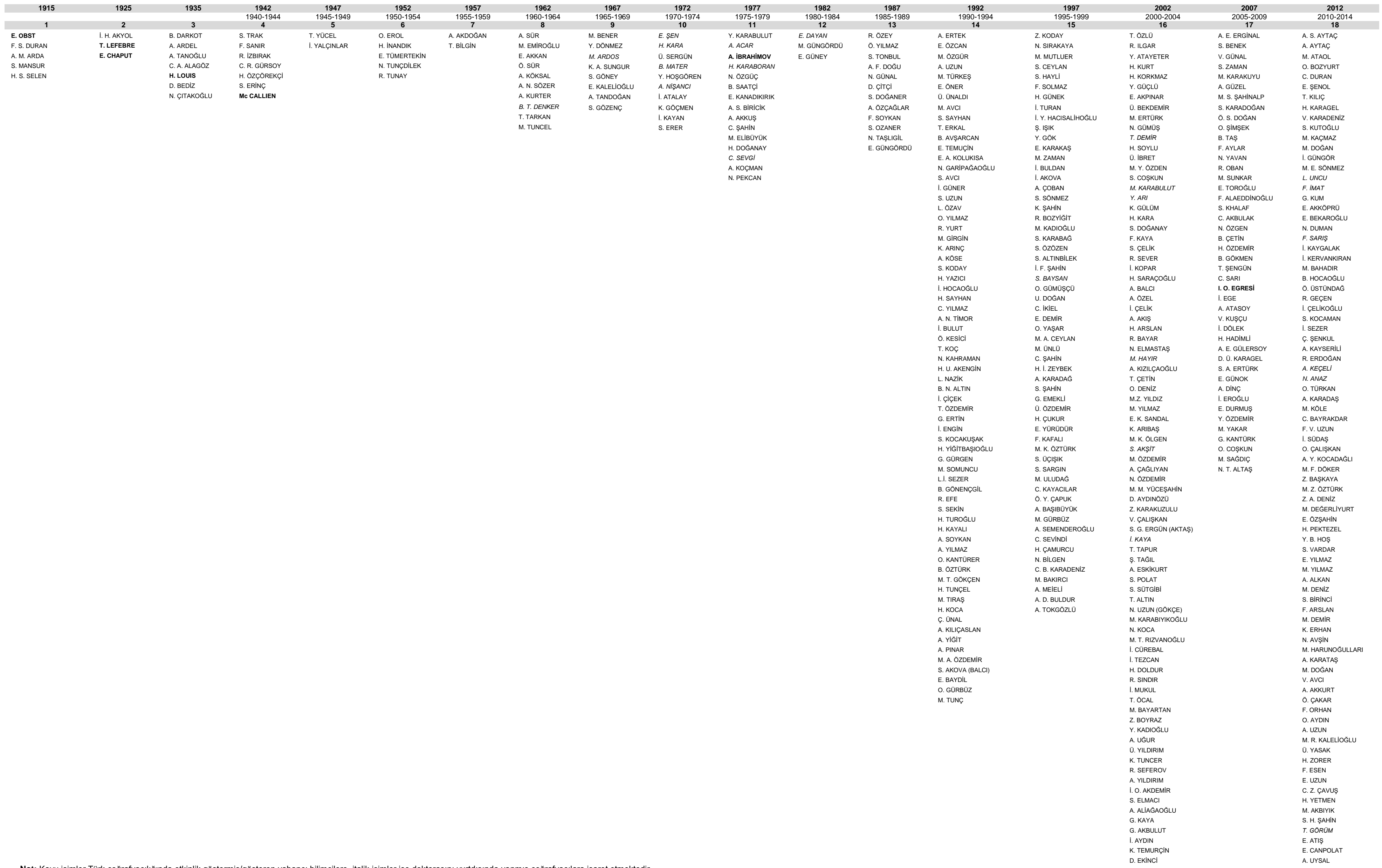

